\title{
Structure of the IGF-binding domain of the insulin- like growth factor-binding protein-5 (IGFBP-5): implications for IGF and IGF-I receptor interactions
}

\author{
Wenzel Kalus, Markus Zweckstetter, \\ Christian Renner, Yolanda Sanchez, \\ Julia Georgescu, Michael Grol ${ }^{1}$, \\ Dirk Demuth ${ }^{1}$, Ralf Schumacher ${ }^{1}$, \\ Carola Dony ${ }^{1}$, Kurt Lang ${ }^{1,2}$ and Tad A.Holak ${ }^{2}$ \\ Max Planck Institute for Biochemistry, D-82152 Martinsried and \\ ${ }^{1}$ Roche Diagnostics Boehringer Mannheim GmbH, Pharma Research, \\ Nonnenwald 2, D-82377 Penzberg, Germany \\ ${ }^{2}$ Corresponding authors \\ e-mail: holak@biochem.mpg.de or Kurt.Lang@Roche.com
}

Binding proteins for insulin-like growth factors (IGFs) IGF-I and IGF-II, known as IGFBPs, control the distribution, function and activity of IGFs in various cell tissues and body fluids. Insulin-like growth factorbinding protein-5 (IGFBP-5) is known to modulate the stimulatory effects of IGFs and is the major IGFbinding protein in bone tissue. We have expressed two N-terminal fragments of IGFBP-5 in Escherichia coli; the first encodes the N-terminal domain of the protein (residues 1-104) and the second, mini-IGFBP-5, comprises residues Ala40 to Ile92. We show that the entire IGFBP-5 protein contains only one high-affinity binding site for IGFs, located in mini-IGFBP-5. The solution structure of mini-IGFBP-5, determined by nuclear magnetic resonance spectroscopy, discloses a rigid, globular structure that consists of a centrally located three-stranded anti-parallel $\beta$-sheet. Its scaffold is stabilized further by two inside packed disulfide bridges. The binding to IGFs, which is in the nanomolar range, involves conserved Leu and Val residues localized in a hydrophobic patch on the surface of the IGFBP-5 protein. Remarkably, the IGF-I receptor binding assays of IGFBP-5 showed that IGFBP-5 inhibits the binding of IGFs to the IGF-I receptor, resulting in reduction of receptor stimulation and autophosphorylation. Compared with the full-length IGFBP-5, the smaller N-terminal fragments were less efficient inhibitors of the IGF-I receptor binding of IGFs.

Keywords: IGFBP-5/insulin-like growth factor/IGF binding/IGF receptor binding/IGF receptor structure

\section{Introduction}

The insulin-like growth factor (IGF) system consists of IGF-I and IGF-II, the IGF-I and IGF-II/M-6-P receptors, IGF-binding proteins (IGFBPs), IGFBP cleaving proteases and an acid-labile subunit (ALS). IGF-I and IGF-II exhibit a broad range of effects on embryonic and fetal growth, development and metabolism (Stewart and Rotwein, 1996). There is also an impressive body of evidence accumulated over the past 10 years that clearly indicates a pivotal role for the IGF system in cancer and in several metabolic disorders such as neurodegenerative diseases and osteoporosis (Walsh, 1995; Rosen et al., 1997; Werner and LeRoth, 1998). IGFs mediate their pleiotropic actions by binding to and activating IGF receptors. IGF action is modulated by a group of six IGF-binding proteins that form high-affinity complexes with both IGF-I and IGF-II (Clemmons, 1997; Rajaram et al., 1997). IGFBPs prevent the insulin-like effects of IGFs, control the half-life of IGFs in blood, act as carrier proteins for IGFs and determine the distribution of IGFs between tissues and extracellular fluids. The affinity of IGFBPs for IGFs is controlled by phosphorylation, glycosylation and, most importantly, by specific proteolysis (Conover, 1995). Insulin-like growth-factor-binding protein-5 (IGFBP-5), the subject of the present study, is known to potentiate the action of IGF-I on smooth muscle cells, fibroblasts or osteoblasts (Bautista et al., 1991). The binding of IGFBP5 to the extracellular matrix or heparins leads to the 8 - to 17-fold decrease of the IGFBP-5 affinity for IGF-I and to enhancement of the biological action of IGF-I on the cells (Jones et al., 1993; Arai et al., 1996; Campbell et al., 1997).

Three-dimensional structures of IGF-I and IGF-II are known (Cooke et al., 1991; Terasawa et al., 1994). However, with the exception of a domain resolution model for the IGF binding to IGFBP-3 (Spencer and Chan, 1995), there is as yet no structural information available on any protein of the IGFBP family. IGFBPs are proteins of 216-289 residues, with mature IGFBP-5 consisting of 252 residues (Rajaram et al., 1997). All IGFBPs share a common domain organization. The highest conservation is found in the $\mathrm{N}$ - (residues 1 to $\sim 100$ ) and $\mathrm{C}$ - (from residue 170) terminal cysteine-rich regions. Twelve conserved cysteines are found in the N-terminal domain and six in the C-terminal domain. The central, weakly conserved part (L-domain) contains most of the cleavage sites for specific proteases (Chernausek et al., 1995). Several different fragments of IGFBPs have been described and biochemically characterized so far (Spencer and Chan, 1995). It is accepted generally that the high-affinity IGF-binding site is located in the N-terminal domain (Zapf et al., 1990; Andress et al., 1993; Chernausek et al., 1995; Fowlkes et al., 1995; Durham et al., 1997; Hashimoto et al., 1997), although Spencer and Chan (1995), Wang et al. (1988) and Ho et al. (1997) suggested that IGFBP-3 and IGFBP-2 contain at least two binding determinants, one in the $\mathrm{N}$ - and one in the $\mathrm{C}$-terminal domain.

In the present paper we have performed the nuclear magnetic resonance (NMR) characterization of IGFBP-5 and its two N-terminal fragments and describe their IGFbinding properties. Furthermore, we show that IGFBP-5 inhibits the IGF-induced activation of the IGF-I receptor. 


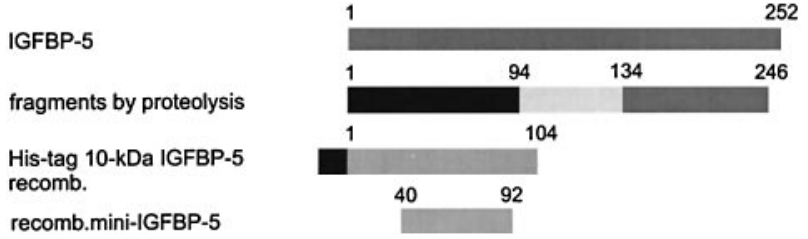

Fig. 1. Overview of the IGFBP-5 fragments. Three fragments, 1-94, 95-134 and 135-246, were obtained by proteolysis of a full-length IGFBP-5 (residues 1-252). Additionally, two recombinant fragments in E.coli were produced [His-tag $10 \mathrm{kDa}$ IGFBP-5(1-104) and miniIGFBP-5].

We also present the three-dimensional structure of the smallest IGFBP-5 domain (mini-IGFBP-5) that contains the primary high-affinity site for IGFs. Based on this structure, a model for the complex between miniIGFBP-5 and IGF-II that satisfies the currently available structural and biochemical data is proposed.

\section{Results}

\section{Proteolysis of IGFBP-5 and construction of recombinant $\mathbf{N}$-terminal fragments}

The full-length human IGFBP-5 was purified from Escherichia coli (Mohan et al., 1995) and subjected to limited proteolysis with endoproteinase Asp N. As indicated in Figure 1, three fragments were produced by proteolysis, the N-terminal fragment containing residues 1-94 (the $10 \mathrm{kDa}$ fragment), the C-terminal fragment with residues 135-246 and a central $4 \mathrm{kDa}$ fragment which spans residues 95-134. During purification of IGFBP-5, an additional $4 \mathrm{kDa}$ fragment was identified which starts at Ala40 and retains binding affinity to IGFs with high affinity (data not shown). All fragments were analysed by SDS-PAGE, N-terminal sequencing and mass spectroscopy. Based on these results, we constructed and expressed two fragments of IGFBP-5 in E.coli. The first fragment, the His-tag $10 \mathrm{kDa}$ IGFBP-5, encloses the complete $\mathrm{N}$-domain of the protein (residues Leu1 to Thr104 plus 13 N-terminal residues of the His-tag) and the second fragment, mini-IGFBP-5, comprises residues Ala40 to Ile92 (plus two N-terminal vector residues).

\section{IGF-binding properties of IGFBP-5 and its fragments}

IGF-binding properties of different fragments were quantitatively analyzed by BIAcore biosensor measurements (Table I; Figure 2). Neither the C-terminal fragment (residues 135-246) nor the mid-regional fragment (residues 95-134) had detectable affinities for immobilized IGF-I or IGF-II (data not shown). Affinities of the $10 \mathrm{kDa}$ fragment (derived from Asp $\mathrm{N}$ cleavage) and recombinant mini-IGFBP-5 were in the nanomolar range, 10- to 200-fold reduced compared with the full-length IGFBP-5 (Table I). For all binding species the association is very fast. Thus the difference in affinity between the truncated and full-length peptides is mainly caused by an increase in the rate of dissociation of the fragments. MiniIGFBP-5 and the $10 \mathrm{kDa}$ fragment have similar affinities for IGFs (Table I). The small difference in affinity of the fragments is predominantly due to faster binding of miniIGFBP-5 to IGFs with very fast kinetics that were beyond the resolution of the instrument. The higher affinity of

\begin{tabular}{lllllc}
\hline \multicolumn{2}{l}{ Table I. BIAcore data } & & & & \\
\hline Analyte & Ligand & $\begin{array}{l}k_{\text {on }} \\
10^{6} / \mathrm{Ms}\end{array}$ & $\begin{array}{l}k_{\text {off }} \\
1 / \mathrm{s}\end{array}$ & $\begin{array}{l}K_{\mathrm{A}} \\
1 / \mathrm{M}\end{array}$ & $\begin{array}{c}K_{\mathrm{D}} \\
\mathrm{nM}\end{array}$ \\
\hline IGFBP-5 & IGF-I & 1.2 & $4.4 \times 10^{-3}$ & $2.7 \times 10^{8}$ & 3.7 \\
& IGF-II & 7.1 & $5.4 \times 10^{-4}$ & $1.3 \times 10^{10}$ & 0.08 \\
mini- & IGF-I & 5.1 & $1.9 \times 10^{-1}$ & $2.7 \times 10^{7}$ & 37 \\
IGFBP-5 & IGF-II & 7.5 & $4.7 \times 10^{-2}$ & $1.6 \times 10^{8}$ & 6.3 \\
10kDa & IGF-I & 1.9 & $3.0 \times 10^{-1}$ & $6.3 \times 10^{6}$ & 158 \\
IGFBP-5 & IGF-II & 1.5 & $2.4 \times 10^{-2}$ & $6.3 \times 10^{7}$ & 16 \\
\hline
\end{tabular}

Summary of the kinetic data of IGF-I and IGF-II binding to IGFBP-5, $10 \mathrm{kDa}$ IGFBP5(1-92), and mini-IGFBP-5. General curve fitting was performed for $250,50,10$ and $2 \mathrm{nM}$ of analyte. A 1:1 binding with mass transfer was used as a model. IGF-I and IGF-II was immobilized on a biosensor.

the full-length IGFBP-5 is caused by the much slower dissociation rate of the complex. Variation of the flow rate clearly demonstrated mass transport effects (data not shown). Therefore we used the highest flow rate of the instrument and low ligand concentrations to minimize rebinding and mass transport, but this may not have been sufficient to exclude these effects completely.

\section{IGFBP-5 modulation of the IGFs' interactions with the IGF-I receptor}

Both IGF-I and IGF-II bind to the IGF-I receptor with high affinity $\left(K_{\mathrm{D}}=1.5\right.$ and $3.0 \mathrm{nM}$, respectively; Loddick et al., 1998). The truncated proteins, as well as the fulllength IGFBP-5, display higher inhibitory potency for IGF-II than for IGF-I; for example, IGFBP-5 has a lower $\mathrm{IC}_{50}$ value for IGF-II $(10 \mathrm{pM})$ than for IGF-I $(40 \mathrm{pM})$. As shown in Figure 3A, preincubation of ${ }^{125}$ I-IGF-II with increasing concentrations of full-length IGFBP-5 resulted in an IGFBP-5 concentration-dependent inhibition of the IGF-II binding to the IGF-I receptor and complete inhibition is observed as soon as IGFBP-5 is in excess of IGF-II (Table II). Similar results were obtained when measuring the influence of the IGFBP-5-IGF complex formation on IGF-mediated stimulation of the IGF-I receptor autophosphorylation (Figure 3B; Table II). These data clearly demonstrate that IGFBP-5 functions as a natural inhibitory protein for IGFs. Mini-IGFBP-5 and the $10 \mathrm{kDa}$ N-terminal fragment showed only weak inhibitory potency. As summarized in Table II, a $10^{3}$-fold excess of these fragments was needed to block IGF-II binding to its receptor. In addition, even a $1 \mu \mathrm{M}$ concentration of the fragments was not sufficient to inhibit the IGF-II-mediated receptor phosphorylation at the IGF-II concentration of $10^{-8} \mathrm{M}$.

\section{Biophysical properties of IGFBP-5 and its fragments}

The IGFBP-5 fragments shown in Figure 1 were also checked for their folding properties with NMR. NMR spectroscopy is a powerful technique for studying foldedunfolded equilibria in macromolecules (Wüthrich, 1986; Zhang and Forman-Kay, 1995). An unfolded protein shows a small dispersion of chemical shifts of amino acid residues (Wüthrich, 1986). This is particularly true for amide resonances which are clustered at $\sim 8.5$ p.p.m. in the proton spectrum of an unfolded protein. NMR spectra of the C-terminal fragment (residues 134-246) revealed sharp 

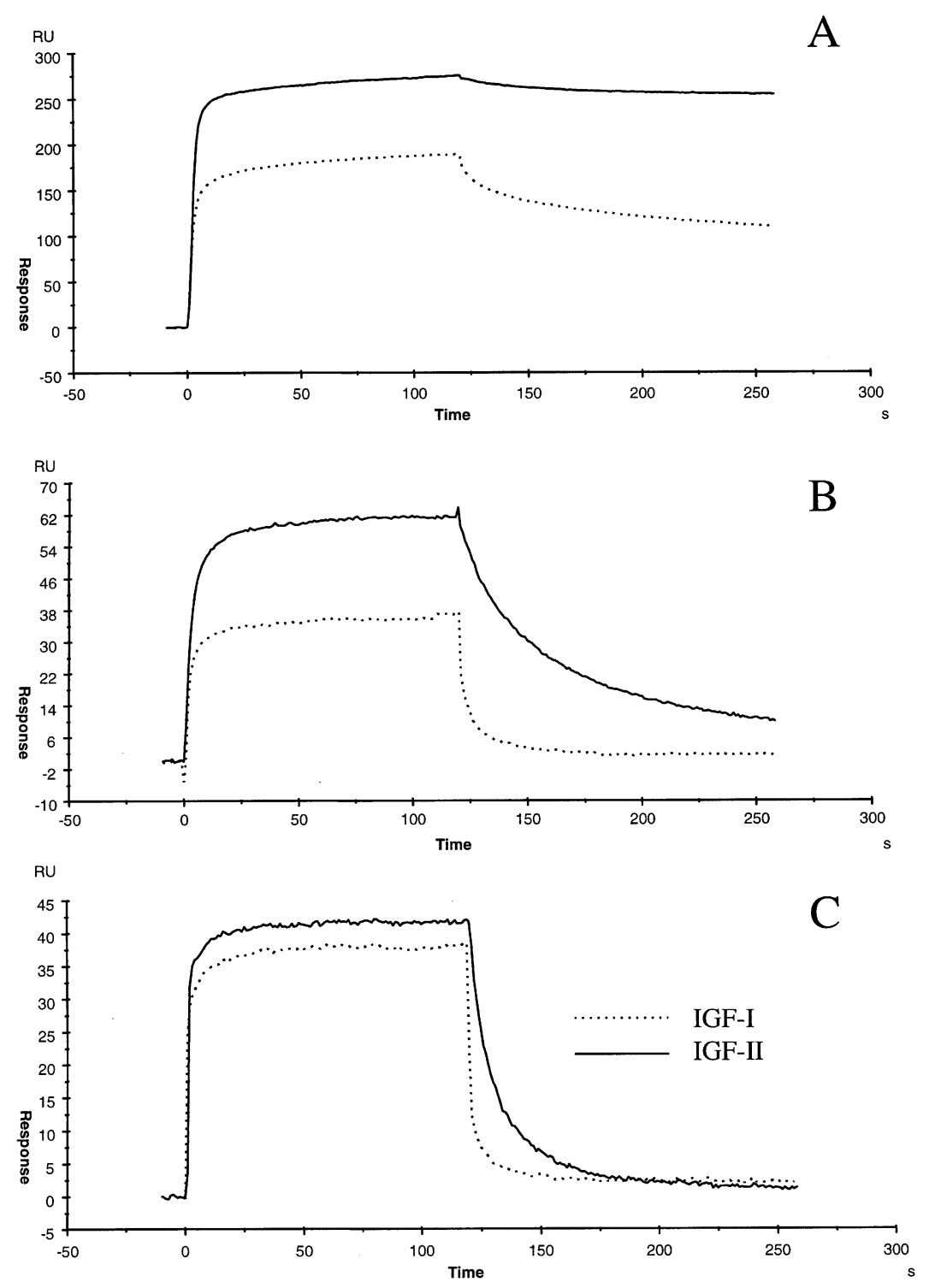

Fig. 2. The IGF binding of IGFBP-5 and its fragments. (A) Sensograms showing the binding of IGFBP-5 to a sensor chip SA coated with $5 \mathrm{nM}$ biotinylated IGF-I and IGF-II. The binding of IGFBP-5 was measured at a concentration of $250 \mathrm{nM}$ at a flow rate of $100 \mu \mathrm{l} / \mathrm{min}$. (B) $10 \mathrm{kDa}$ IGFBP-5. (C) mini-IGFBP-5.

resonance lines at 8.5 p.p.m., which together with the resonance intensity pattern of the up-field-shifted aliphatic resonances $(0.3$ to -0.2 p.p.m.) versus the intensity of the bulk aliphatic resonance lines at 0.8 p.p.m., allowed us to estimate that $\sim 40 \%$ of the C-terminal fragment was in a random coil conformation. The $4 \mathrm{kDa}$ fragment (residues 93-134) exhibited an NMR spectrum typical for an unstructured peptide. This is in agreement with the suggestion that the central, weakly conserved L-domain has a high conformational flexibility (Spencer and Chan, 1995). Mini-IGFBP-5 and the His-tag $10 \mathrm{kDa}$ N-terminal fragment IGFBP-5(1-104) are folded in solution, as can be seen from the HSQC spectra of Figure 4A, which clearly shows that mini-IGFBP-5 and both parts 1-39 and 40-92 of the IGFBP-5 (1-104) are structured.

The two recombinant N-terminal constructs showed the presence of higher than monomeric species in solution. Spectra for ${ }^{1} \mathrm{H},{ }^{15} \mathrm{~N}$ and ${ }^{13} \mathrm{C}$ exhibited line widths broader than those expected for monomeric proteins at concentra- tions between 0.2 and $1.5 \mathrm{mM}$. At $\mathrm{pH} 3.7,{ }^{15} \mathrm{~N}$ relaxation and other line width data indicated a possible monomericdimeric equilibrium for mini-IGFBP-5 and higher oligomerization states for the $10 \mathrm{kDa}$ construct $1-104$. As a result of this increased aggregation, the quality of NOESY (two-dimensional nuclear Overhauser effect spectroscopy) spectra of the His-tag $10 \mathrm{kDa}$ IGFBP-5 were such that they were not suitable for a detailed NMR analysis. At $\mathrm{pH}$ 6.5, a dramatic increase of line widths $\left({ }^{1} \mathrm{H}\right.$ amide line widths $35 \mathrm{~Hz}$ ) suggested higher oligomerization states for both peptides. Dilution of the proteins from 1.0 to $0.4 \mathrm{mM}$ had only a small beneficial effect on line widths. Therefore, oligomerization properties of mini-IGFBP-5 were studied with NMR using mini-IGFBP-5 prepared by mixing 1:1 the ${ }^{13} \mathrm{C} /{ }^{15} \mathrm{~N} /{ }^{1} \mathrm{H}$-labelled and ${ }^{12} \mathrm{C} /{ }^{14} \mathrm{~N} /{ }^{1} \mathrm{H}$-unlabelled protein. With this sample it is possible to determine intermolecular NOE interactions provided that defined and NMR longlived oligomers are present in solution (Zwahlen et al., 1997). No intermolecular NOEs (nuclear Overhauser 
effect) could be detected for mini-IGFBP-5 in the NMR spectra, indicating that the increase of NMR line widths is due to unspecific aggregation of the protein. We also checked for the presence of multiple conformations or nonnative $\mathrm{S}-\mathrm{S}$ states by NOESY, TOCSY (total correlation
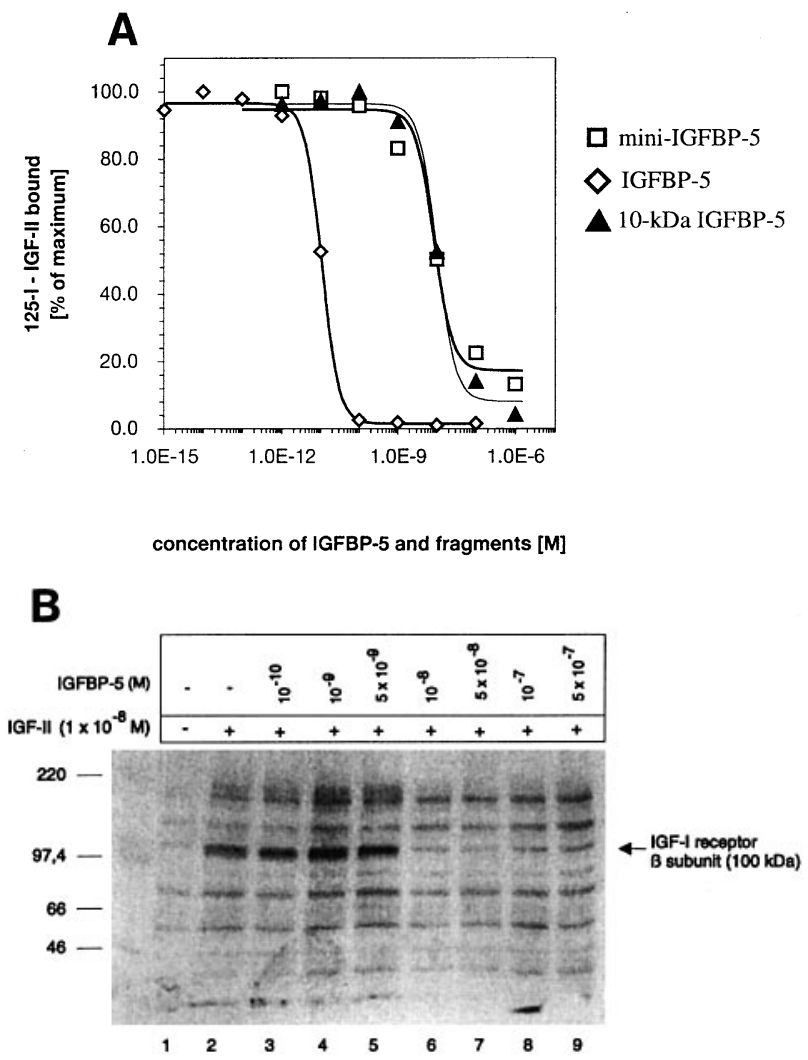

Fig. 3. Inhibition of IGF-II-mediated responses by different IGFBP-5 peptides. (A) Inhibition of ${ }^{125}$ I-IGF-II binding by different IGFBP-5 peptides to the intact NIH 3 T3 cells expressing IGF-IR. (B) Inhibition of IGF-II-stimulated IGF-IR phosphorylation by preincubation of IGF-II with increasing concentrations of IGFBP-5. Confluent monolayers of NIH $3 \mathrm{~T} 3$ cells expressing IGF-IR were starved for $48 \mathrm{~h}$. After stimulation with either $10^{-8} \mathrm{M}$ IGF-II alone (lane 2) or in a combination of different concentrations of IGFBP-5 (lanes 3-9) or no hormone (lane 1) for $10 \mathrm{~min}$ at $37^{\circ} \mathrm{C}$, medium was removed, and cells were lysed for $10 \mathrm{~min}$ on ice. After lysis, the insoluble material was separated by centrifugation, and the supernatant was analysed by Western blotting with a monoclonal anti-phosphotyrosine antibody after SDS-PAGE. Molecular weight standard as indicated. spectroscopy) and ROESY (rotating frame Overhauser effect spectroscopy) spectra. Mini-IGFBP-5 has four cysteines that are known to participate in disulfide bridges (see below). In principle, a mixture of three different $\mathrm{S}-\mathrm{S}$ pairs was possible for these four cysteines because their side-chains are all located in the center of the protein structure and are close to each other (Figure 5A). However, all NMR and other biophysical data (elution in one sharp peak from the reversed-phase HPLC analysis, unfolding and refolding properties) indicated that a single mini-IGFBP-5 molecule had a unique conformation in solution. Therefore, we concluded that the NMR line broadening is due to unspecific aggregation. Adding mild detergents, such as CHAPS, or increasing salt concentration did not improve the spectra. Lowering the $\mathrm{pH}$ of the sample from $\mathrm{pH} 6.5$ to 3.7 proved to be a single determining factor in reducing the extent of aggregation. Formation of the complex between mini-IGFBP-5 and IGFs leads to additional broadening of all NMR resonances to such an extent that no quantitative NMR structural evaluation of the spectra was possible. So far, an attempt to crystallize the complex has not been successful.

\section{Three-dimensional structure of mini-IGFBP-5}

Stereo views of the three-dimensional structure of miniIGFBP-5 calculated from 385 approximate distance and 84 torsion angle constraints are shown in Figure 5A and B. Table III shows data for qualities of the calculated structures. A total of 90 structures was calculated by a simulated annealing protocol (Brünger and Nilges, 1993). A family of the 20 best structures was selected using total energies as selection criteria (Figure 5A). All structures satisfy the experimental constraints with small deviations from idealized covalent geometry (Table III). The average atomic root mean square deviations (r.m.s.d.) for heavy atoms of residues Ala40-Pro62 and Pro69Tyr86 among the structures were $0.32 \pm 0.16 \AA$ for the backbone atoms and $0.83 \pm 0.40 \AA$ for all atoms. For the whole protein (excluding Arg86 to Ile92) the r.m.s.d. values were $0.68 \pm 0.42 \AA$ for the backbone atoms and $1.69 \pm 0.65 \AA$ for all atoms.

Three short anti-parallel $\beta$-strands (residues 46-47, 58-61 and 78-82) together with two cysteine bridges are responsible for a compact and uniquely defined fold of mini-IGFBP-5. A solvent-exposed loop between Pro62

Table II. Inhibitory characteristics of full-length IGFBP-5 and N-terminal fragments

\begin{tabular}{llll}
\hline Analyte & Ligand & $\begin{array}{l}\text { IC } 50 \text { value using } 5 \times 10^{-12} \mathrm{M} \text { [ }^{125} \text { I]IGF-I } \\
\text { or IGF-II for binding to IGF-IR }\end{array}$ & $\begin{array}{l}\text { IC } 50 \text { value using } 5 \times 10^{-9} \text { M IGF-I } \\
\text { or } 10^{-8} \text { M IGF-II to stimulate IGF-IR autophosphorylation }\end{array}$ \\
\hline IGFBP-5 & IGF-I & $4 \times 10^{-11}$ & $10^{-9}-5 \times 10^{-9}$ \\
& IGF-II & $1 \times 10^{-11}$ & $5 \times 10^{-9}-10^{-8}$ \\
mini- & IGF-I & $1 \times 10^{-7}$ & $>10^{-6}$ \\
IGFBP-5 & IGF-II & $1 \times 10^{-8}$ & $>10^{-6}$ \\
$10 \mathrm{kDa}$ & IGF-I & $3 \times 10^{-7}$ & $>10^{-6}$ \\
IGFBP-5 & IGF-II & $1 \times 10^{-8}$ & \\
IGF-I & IGF-I & $4.5 \times 10^{-9}$ & \\
& IGF-II & $1 \times 10^{-10}$ & \\
IGF-II & IGF-I & $1.5 \times 10^{-8}$ & \\
& IGF-II & $7 \times 10^{-10}$ & \\
\hline
\end{tabular}

Receptor binding analyses were performed as described in Figure $3 \mathrm{~A}$, receptor phosphorylation analyses as described in Figure $3 \mathrm{~B}$. $\mathrm{IC}_{50}=$ molar concentration of IGFBP-5, fragments or IGFs (cold) required to reduce the binding of iodinated ligand to receptors or the stimulation of IGF-IR autophosphorylation by $50 \%$. 
W.Kalus et al.
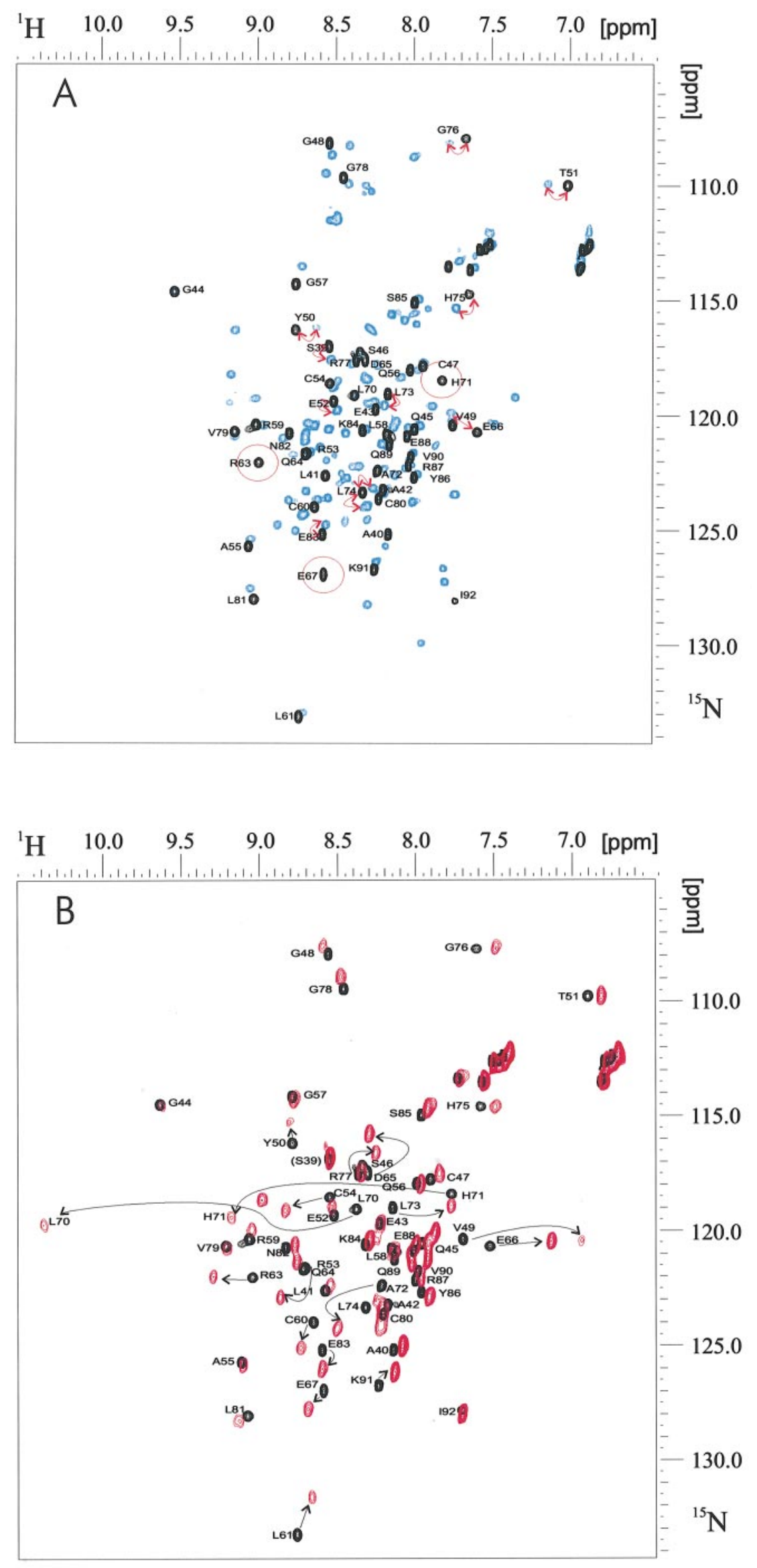
and Pro69 is the least precisely defined segment of the structure and five C-terminal residues of mini-IGFBP-5 are unstructured. Relaxation measurements for ${ }^{15} \mathrm{~N}$ indicate that the backbone of the variable loop 62-69 does not exhibit any fast picosecond time-scale motions; instead the loop residues in the IGF uncomplexed mini-IGBP-5 show contributions from slower millisecond exchange processes (data not shown). IGF complex formation, however, imposes rigidification of this loop. The cysteine bonds are formed between Cys47 and Cys60, and Cys54 and Cys80. These $\mathrm{S}-\mathrm{S}$ pairings fit the experimental data best, displaying, for example, characteristic NOE patterns between $\beta-\beta$ methylene groups of these residues (Klaus et al., 1993), although, as mentioned above, the S-S isomerization or different $S-S$ pairing would cause little structural modification. Our assignment of the disulfide bond pattern in mini-IGFBP-5 is in agreement with the pattern of the two bridges recently determined for IGFBP-3 by peptide mapping (Hashimoto et al., 1997).

\section{Mapping the binding site of IGF-II on mini-IGFBP-5}

Mapping the binding site of IGF-II on mini-IGFBP-5 with NMR was accomplished by monitoring chemical shift changes (Craik and Wilce, 1997) of the backbone and most of the side-chain proton and carbon atom resonances (Figures 4B, C and 6). Since mini-IGFBP-5 forms a tight complex with IGF-II (and IGF-I), numerous residues in the HSQC spectra show pairs of well-resolved peaks corresponding to free and IGF-II-bound states upon addition of IGF-II to the ${ }^{15} \mathrm{~N}$-labelled mini-IGFBP-5, for example, in the ratio $0.5: 1.0$, respectively. The largest IGF-induced chemical shifts were observed for residues Val49, Tyr50, Pro62 and Lys68 to Leu75 (Figure 6). These induced shifts (especially the $\boldsymbol{S N}$ parameters, see Materials and methods) are directly proportional to the strength of the intermolecular interaction of the residues in the binding cleft in the first approximation. These residues form the major IGF-binding region of mini-IGFBP-5. As can be seen from Figure 6, the binding site residues can be determined from independent NMR titrations of different types of nuclei $\left({ }^{1} \mathrm{H}^{\mathrm{N}},{ }^{15} \mathrm{~N}\right.$ or ${ }^{13} \mathrm{C}$; see Figure 6). In addition, an assignment of several intermolecular IGF-II-IGFBP-5 NOEs for Val49, Leu70, Leu73 and Leu74 was obtained from the half-filter NMR spectra (Zwahlen et al., 1997) using the ${ }^{13} \mathrm{C} /{ }^{15} \mathrm{~N}$-labelled mini-IGFBP-5 complexed to unlabelled IGF-II. NOESY patterns of free and bound mini-IGFBP-5 are similar, indicating little change in the structure of mini-IGFBP-5 upon binding to IGF-II.

The ${ }^{15} \mathrm{~N}$ NMR IGF-II titration was also carried out for the recombinant His-tag $10 \mathrm{kDa}$ IGFBP-5(1-104). As can be seen in Figure 4, it was possible to assign most of the HSQC peaks of the free and complexed mini-IGFBP-5 fragment in the HSQC spectra of the free and complexed $10 \mathrm{kDa}$ IGFBP-5(1-104). The remaining unassigned peaks

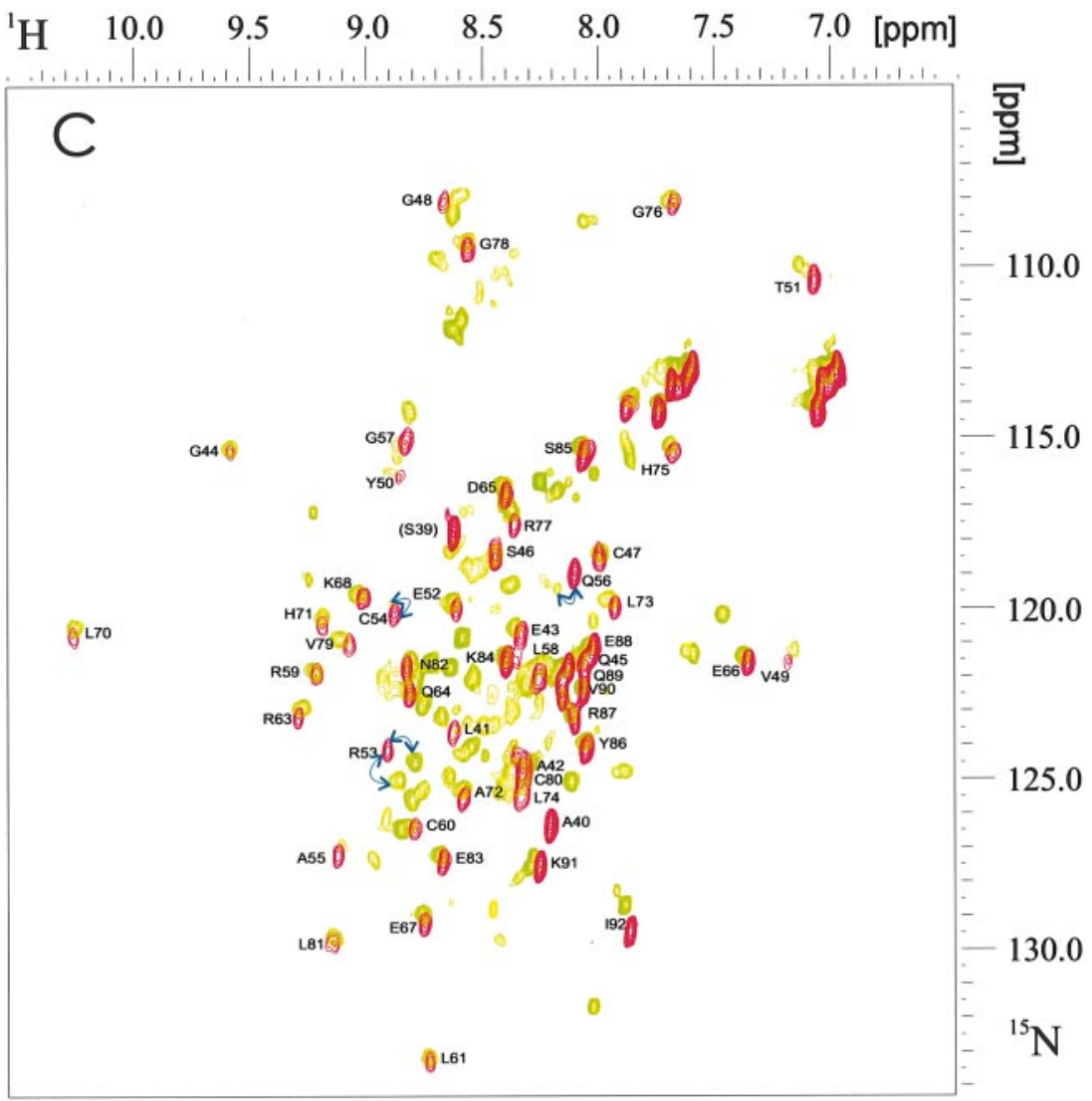

Fig. 4. ${ }^{1} \mathrm{H}_{-}{ }^{15} \mathrm{~N}$ HSQC spectrum of the uniformly ${ }^{15} \mathrm{~N}$-labelled mini-IGFBP-5 and $10 \mathrm{kDa}$ IGFBP-5 (1-104) at $\mathrm{pH}$ 4.5. (A) Overlay of ${ }^{1} \mathrm{H}-{ }^{15} \mathrm{~N}$ HSQC spectra of free mini-IGFBP-5 (black) and free $10 \mathrm{kDa}$ IGFBP-5 (blue). Small shifts are observed for resonances of residues 41-90 (arrows). Some peaks (circles) could not be assigned for the $10 \mathrm{kDa}$ IGFBP-5. The cross-peak from His71 is visible at pH 5.0. Ser39 belongs to the thrombin cleavage site of mini-IGFBP-5 and therefore is not present in the HSQC of $10 \mathrm{kDa}$ IGFBP-5. (B) Overlay of ${ }^{1} \mathrm{H}-{ }^{15} \mathrm{~N}-\mathrm{HSQC}$ spectra of free (black) and complexed (red) mini-IGFBP-5. Arrows connect resonances of free and complexed forms. (C) Overlay of ${ }^{1} \mathrm{H}^{-}{ }^{15} \mathrm{~N}$ HSQC spectra of complexed mini-IGFBP-5 (red) and complexed 10 kDa IGFBP-5 (green). Almost no difference in chemical shifts is observed for the assigned resonances. 

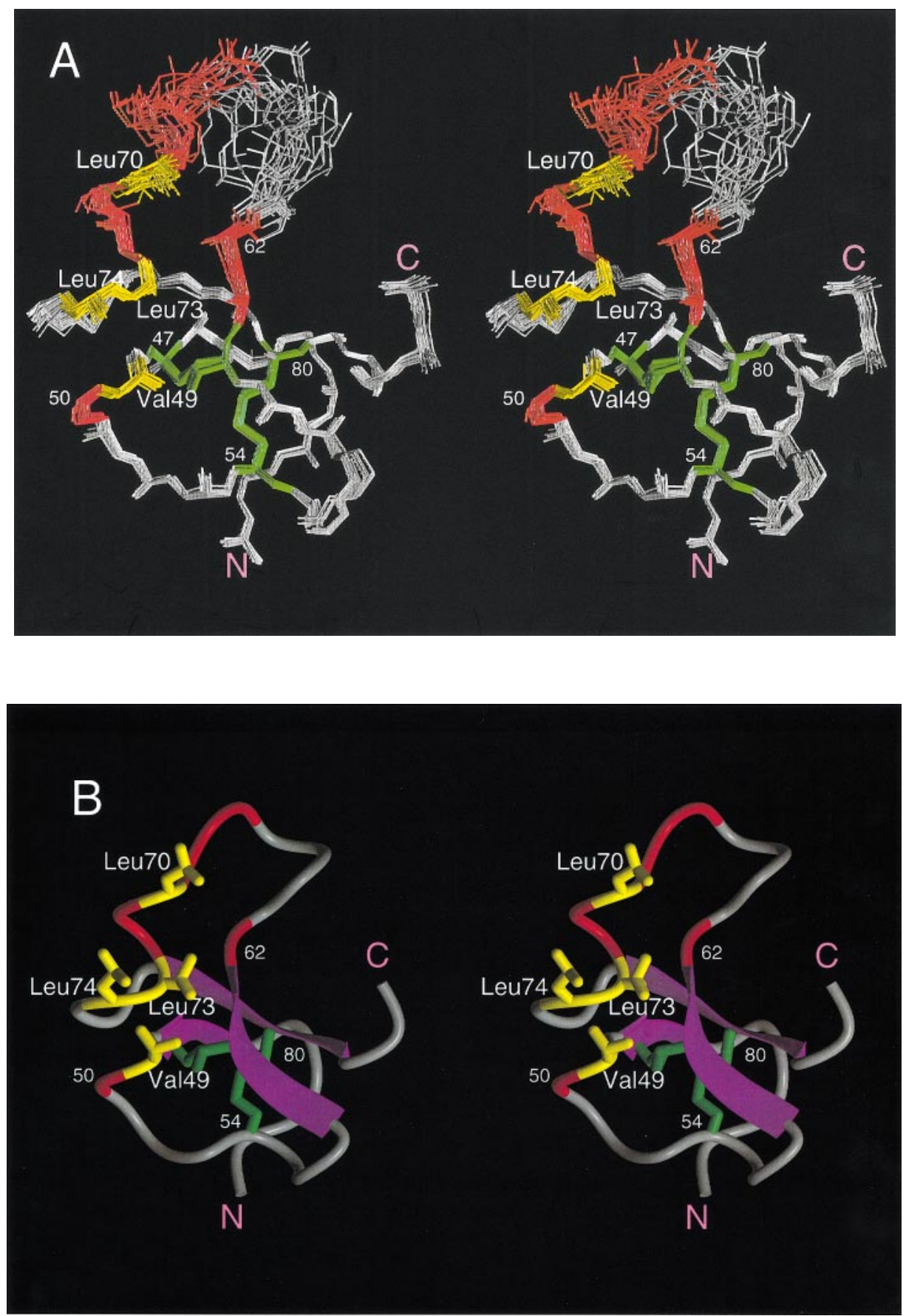

in HSQC spectra of $10 \mathrm{kDa}$ IGFBP-5(1-104) arise from the His-tag, the N-terminal 39 residues and 12 additional $\mathrm{C}$-terminal residues. They also show very small changes in chemical shifts between free and complexed $10 \mathrm{kDa}$ IGFBP-5(1-104). Differences in amide proton and nitrogen chemical shifts between the N-terminal $10 \mathrm{kDa}$ domain and the mini-IGFBP-5 are small, especially for the complexed peptides. Therefore, we conclude that the first 39 residues of IGFBP-5 constitute an independent domain (with three proposed disulfide bridges) that has no structural influence on the following mini-IGFBP-5 domain.

\section{Discussion}

Mini-IGFBP-5 has a compact and globular 3D structure whose scaffold is secured by an inside packing of two cysteine bridges stabilized further by a three-stranded $\beta$-sheet. The mini-IGFBP-5 fold seems to be unique; we found no similar fold in database searches. The present NMR study shows unequivocally that the primary IGF-binding site comprises residues Val49, Tyr50, Pro62 and Lys68 to Leu75, exclusively located in the miniIGFBP-5 domain of the N-terminal part of IGFBP-5. No binding is expected in the first N-terminal 39 residues of IGFBP-5, as shown by the NMR titration and BIAcore 


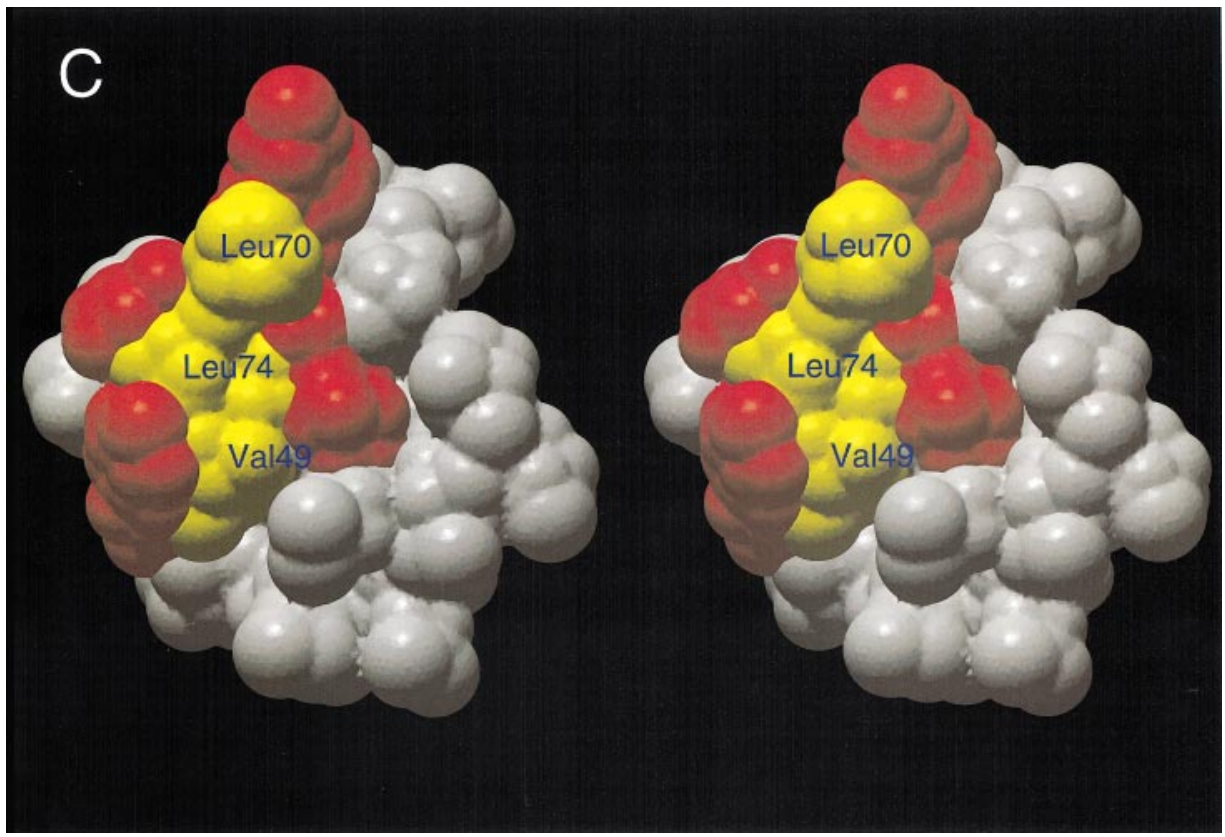

Fig. 5. The three-dimensional structure of mini-IGFBP-5. Residues showing large chemical shifts upon IGF complexation are red, residues with additional intermolecular NOEs to IGFs are yellow. The cysteine bridges are green. Figures were created using the MOLMOL program (Koradi et al., 1996). (A) Stereo view of the backbone atoms (N, $\left.\mathrm{C}^{\alpha}, \mathrm{C}\right)$ of the final ensemble of 20 mini-IGFBP-5 structures best fit to $\mathrm{N}$, $\mathrm{C}^{\alpha}$ and $\mathrm{C}$ atoms of residues 40-62 and 69-86. (B) Ribbon drawing of mini-IGFBP-5 showing its $\beta$-sheet, the cysteine bridges and the residues composing the hydrophobic patch. (C) Solid surface model of mini-IGFBP-5.

\section{Difference of Chemical Shift between free and complexd mini-IGFBP-5}

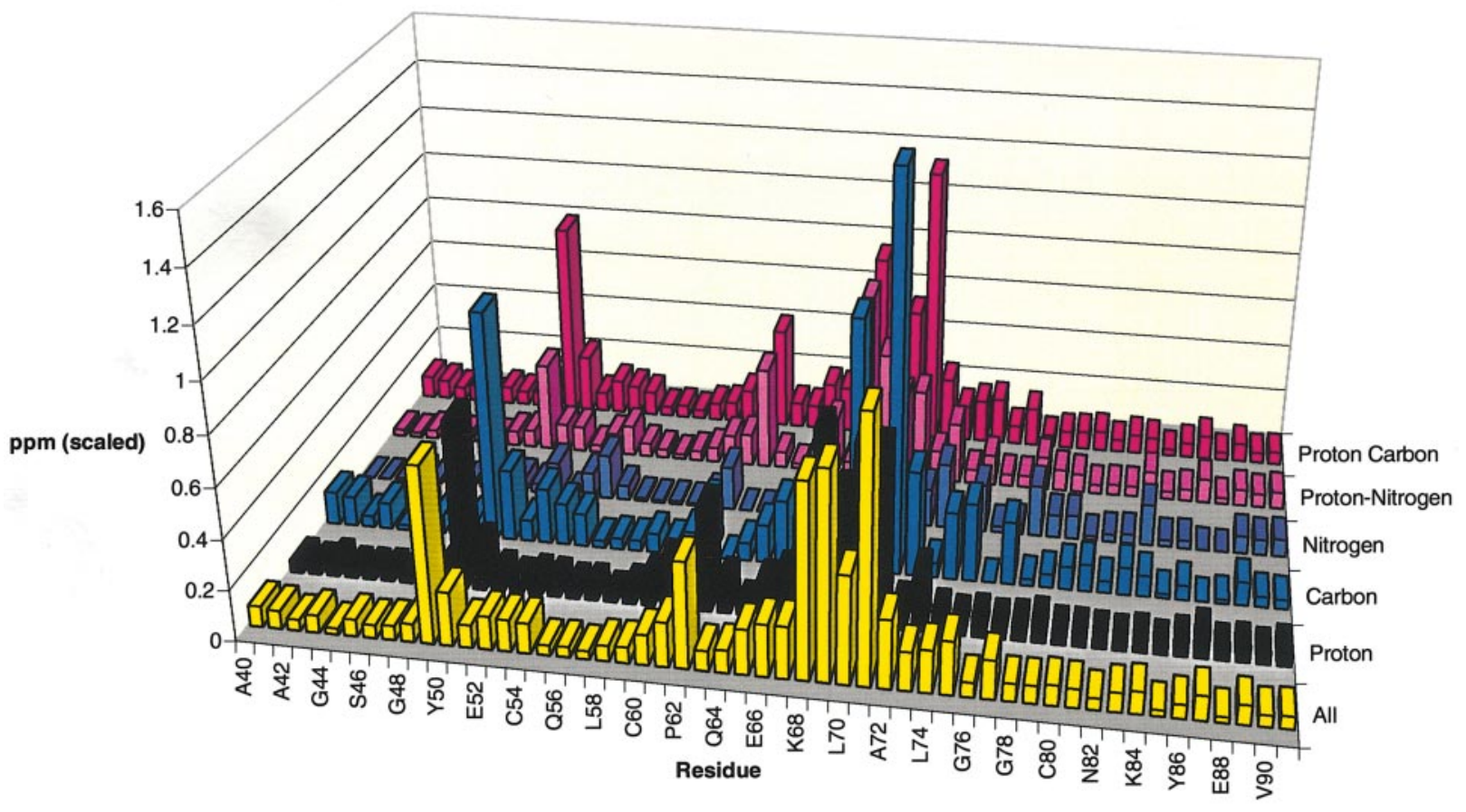

\section{$\square$ All $\square$ Proton $\square$ Carbon $\square$ Nitrogen $\square$ Proton-Nitrogen $\square$ Proton Carbon}

Fig. 6. Differences in chemical shifts of free and IGF-complexed mini-IGFBP-5. Difference of chemical shifts of the IGF-II-complexed and free mini-IGFBP-5 for all residues. Shift differences are scaled and combined with different sets (see experimental procedures): all, corresponds to the combination of carbon, nitrogen and proton shifts (averaged); proton, to the combination of $\mathrm{H}^{\alpha}, \mathrm{H}^{\beta}, \mathrm{H}^{\gamma}, \mathrm{H}^{\delta}$, and $\mathrm{H}^{\mathrm{N}}$ shifts, carbon to $\mathrm{C}^{\alpha}$ and $\mathrm{C}^{\beta}$-shifts; nitrogen, to ${ }^{15} \mathrm{~N}$ shifts; proton-nitrogen, to ${ }^{1} \mathrm{H}^{\mathrm{N}}$ and ${ }^{15} \mathrm{~N}$ shifts; and proton-carbon, to proton and ${ }^{13} \mathrm{C}$. Non-assigned signals appear as zero. Large shifts indicate residues involved in the IGF binding. 


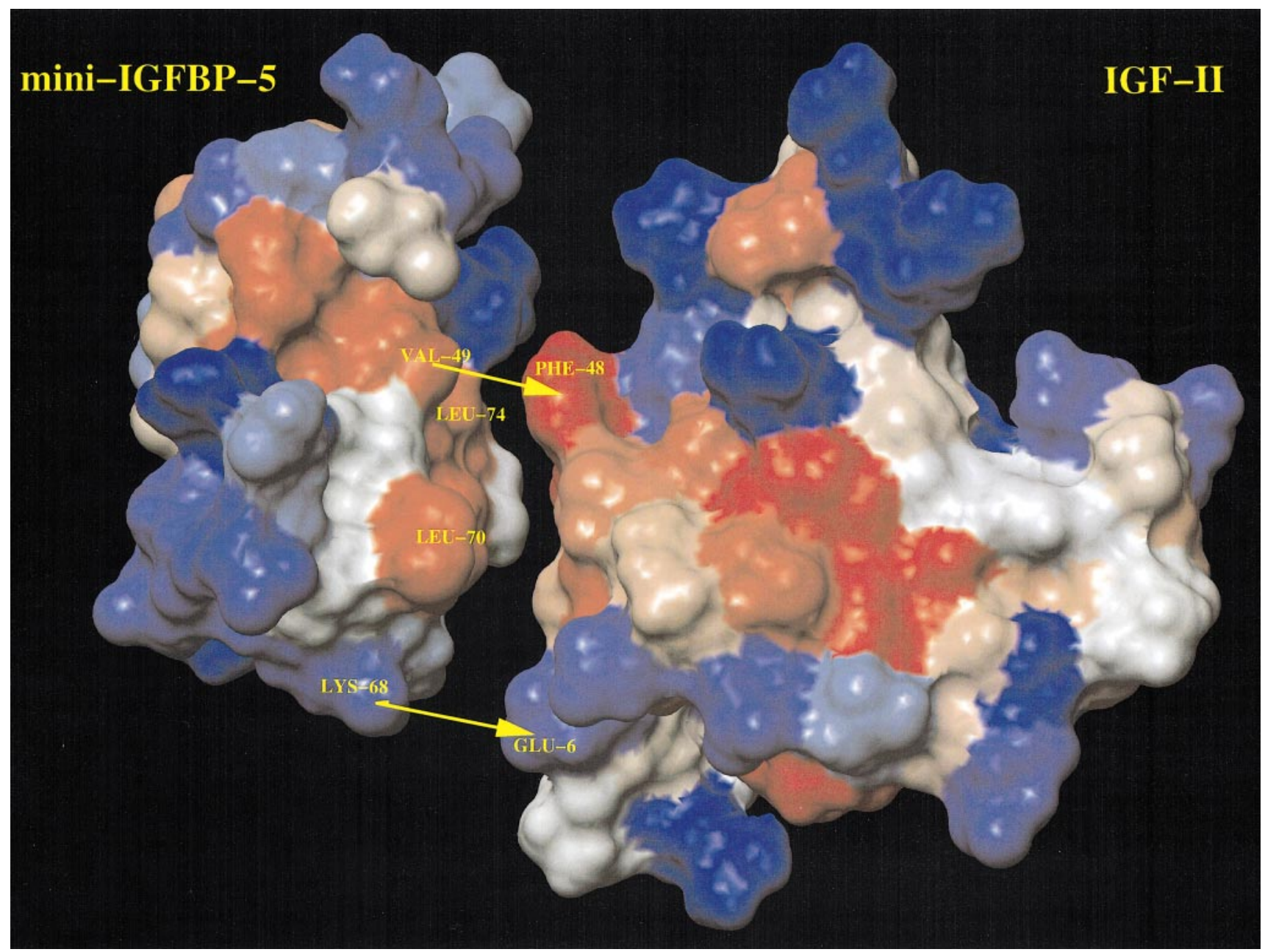

Fig. 7. Model of IGF-II binding to mini-IGFBP-5. The arrows connect binding areas. Phe48 of IGF-II docks to the hydrophobic patch of miniIGFBP-5 composed of Val49, Leu70 and Leu74. Glu6 of IGF-II interacts with Lys68 of the hydrophilic and variable loop of mini-IGFBP-5. Surfaces are colored according to hydrophobic properties (red, hydrophobic; white, neutral; blue, hydrophilic). Computational results obtained using Insight II (Insight, 1995).

binding measurements of mini-IGFBP-5 and the larger $10 \mathrm{kDa}$ fragments that include the $39 \mathrm{~N}$-terminal residues. For IGFBP-2, it was shown that Tyr60 (which corresponds to Tyr50 in IGFBP-5) was protected against iodination upon binding of IGFBP-2 to IGF-II (Hobba et al., 1996) suggesting that this residue is close to the IGF-binding site, in agreement with our data. The C-terminal fragment (residues 135-246) and the mid-regional fragment (residues 95-134) bind neither IGF-I nor IGF-II.

The affinities of mini-IGFBP-5 and of the longer $10 \mathrm{kDa}$ fragment to IGF-I and IGF-II are in the nanomolar range; the interaction of mini-IGFBP-5 with IGFs is very strong. A life-time of the IGF-II-mini-IGFBP-5 complex is $5 \mathrm{~s}$ $\left(k_{\text {off }}=1.9 \times 10 \mathrm{~s}^{-1}\right.$; Table I). The BIAcore measurements showed that these affinities are 10- to 200-fold lower compared with those of the full-length IGFBP-5, which agrees well with the reported reduced affinities of other C-terminally truncated fragments of IGFBP-3 (Clemmons, 1993) and IGFBP-5 (Andress et al., 1993). The higher affinity of the full-length IGFBP-5 is most probably caused by secondary interactions of the residues from the neighbouring to mini-IGFBP-5 domains. Since the $K_{\mathrm{D}}$ values for mini-IGFBP-5 and the $10 \mathrm{kDa}$ fragment do not differ significantly, residues located at the $\mathrm{C}$-terminal from the $10 \mathrm{kDa}$ segment (residues 105-246) must be involved in the additional stabilization of the IGF complexation in the intact IGFBP-5 protein. These findings are consistent with a recent study of IGF binding in IGFBP-4 (Qin et al., 1998). Deletion analysis using IGFBP-4 expressed in bacteria revealed that the N-terminal sequence Leu72Ser91 was essential for IGF binding. The C-terminal fragments (His121-Glu237 or Arg142-Glu237) did not bind to IGF but loss of these regions decreased IGFbinding activity. Detailed deletion analysis identified the residues Cys205-Val214 as the motif to facilitate IGF binding (Qin et al., 1998). Our BIAcore and NMR IGFbinding data indicate a common principle for the binding of IGFs by all IGFBPs. This model is consistent with recent reports on the IGF binding of fragments of IGFBP-3 (Fowlkes et al., 1995; Hashimoto et al., 1997) and IGFBP-4 (Chernausek et al., 1995; Qin et al., 1998), using methods other than BIAcore and NMR, but contradicts reports that indicated substantial IGF binding in the C-domain of IGFBP-3 (residues 151-263) (Wang et al., 1988; Spencer and Chan, 1995) and IGFBP-2 (Ho et al., 1997).

Although the structure of the mini-IGFBP-5-IGF complex would be the most desirable for explaining inter- 


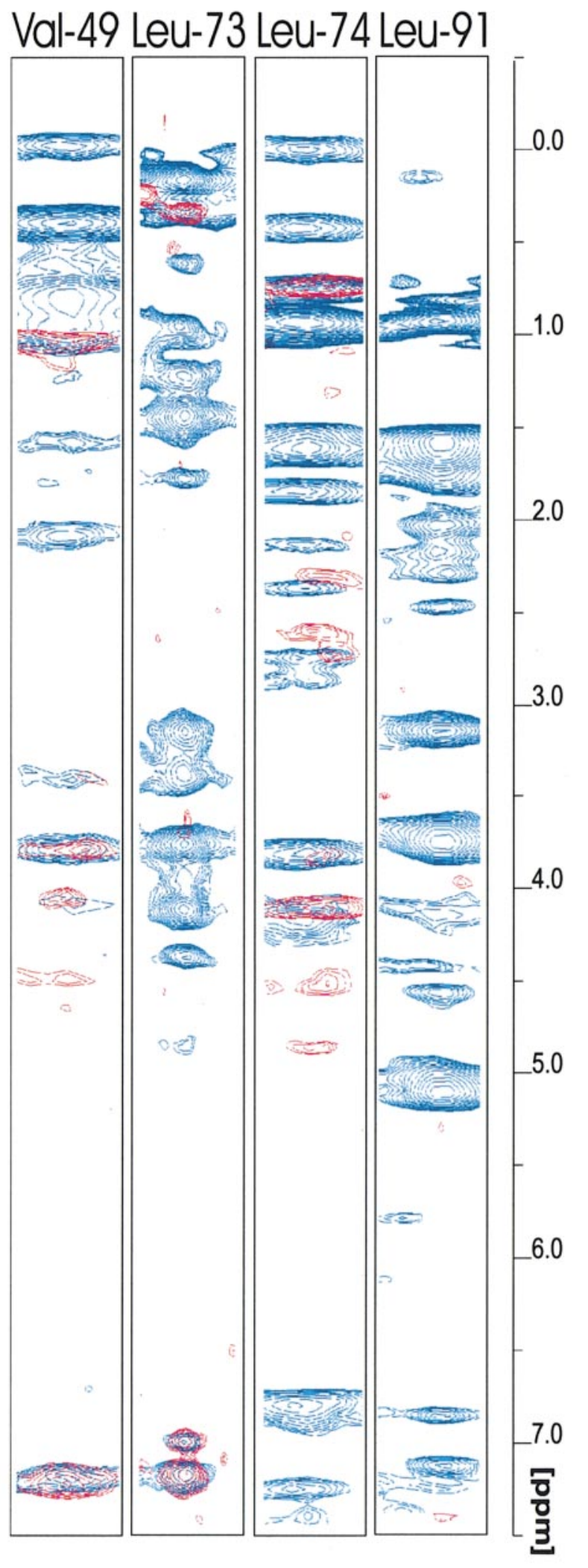

Fig. 8. The $\mathrm{F}_{1}-\mathrm{F}_{2}$ stripes of the ${ }^{13} \mathrm{C}-{ }^{1} \mathrm{H}$ NOESY-HSQC spectra of the IGF-II-mini-IGFBP-5 complex at the ${ }^{1} \mathrm{H}$ methyl frequencies of residues 49, 73, 74 and 91 of mini-IGFBP-5 showing their NOEs to residues of mini-IGFBP-5 and IGF-II (blue) and intermolecular NOEs to IGF-II (red).
Table III. Average deviations from ideality, energies of the structures, and r.m.s.d. between experimental and calculated distance constraints

\begin{tabular}{|c|c|}
\hline Parameter & $<\mathrm{SA}>$ \\
\hline \multicolumn{2}{|c|}{ Deviations from idealized geometry } \\
\hline bonds $(\AA)$ & $0.006 \pm 0.001$ \\
\hline angles (deg.) & $0.706 \pm 0.030$ \\
\hline impropers (deg.) & $0.498 \pm 0.036$ \\
\hline \multicolumn{2}{|l|}{ Energies $(\mathrm{kcal} / \mathrm{mol})$} \\
\hline $\mathrm{E}_{\mathrm{NOE}}$ & $29.4 \pm 4.5$ \\
\hline $\mathrm{E}_{\text {tor }}$ & $2.2 \pm 0.3$ \\
\hline$E_{\mathrm{vdW}}$ & $6.1 \pm 0.7$ \\
\hline \multicolumn{2}{|c|}{ Number of residual constraint violations for all constraints } \\
\hline $0.3 \AA<$ r.m.s.d. $\leqslant 0.4 \AA$ & $4.0 \pm 2.3$ \\
\hline $0.4 \AA<$ r.m.s.d. $\leqslant 0.5 \AA$ & $0.1 \pm 0.2$ \\
\hline$>0.5 \AA$ & 0.0 \\
\hline \multicolumn{2}{|c|}{ r.m.s.d. from experimental distance constraints $(\AA)$} \\
\hline all (384) & $0.048 \pm 0.009$ \\
\hline interresidue $(|\mathrm{i}-\mathrm{j}|<5)(221)$ & $0.030 \pm 0.007$ \\
\hline long-range (112) & $0.054 \pm 0.006$ \\
\hline H-bond distances (8) & $0.050 \pm 0.008$ \\
\hline intraresidue (32) & $0.046 \pm 0.007$ \\
\hline intraresidue (32) & $0.046 \pm 0.007$ \\
\hline
\end{tabular}

$<$ SA $>$ represents the ensemble of the 20 final structures. Force constants used to calculate energy terms are the same as reported previously (Holak et al., 1989). The r.m.s.d. from the interproton distance constraints were calculated as described in Holak et al. (1989). The number of distance constraints is given in parentheses.

actions between IGFBPs and IGFs, it has so far proved elusive, possibly because of a tendency for the complex to aggregate. However, our NMR mapping study of miniIGFBP-5 together with mutagenesis studies of IGFs enables modelling of the IGF-IGBP interaction with a high degree of confidence. A number of hydrophobic residues, Val49, Leu70 and Leu74, expose their sidechains into solution defining a hydrophobic patch on the surface of mini-IGFBP-5 (Figures 5 and 7). Several intermolecular NOE connectivities were observed from these residues to the proton resonances of the aromatic side-chains of IGF-II (Figure 8). Site-directed mutagenesis studies on IGFs indicate that IGF residues Glu6, Phe48, Arg49 and Ser50 are important for binding to IGFBPs (Luthi et al., 1992; Bach et al., 1993; Francis et al., 1993; Jansson et al., 1997). It was suggested also that Phe26 of IGFs plays a role in changing the local structures of IGFs but does not bind directly to IGFBPs (Terasawa et al., 1994). Thus, Phe 48 of IGFs remains the prime aromatic residue that could bind to the hydrophobic patch of IGFBP-5. The hydrophobic residues Val49, Leu73 and Leu74 of IGFBP-5 are highly conserved among all IGFBPs. We therefore concluded that this hydrophobic interaction dominates the IGF-binding properties of IGFBP-5. Based on these considerations, the miniIGFBP-5 and IGF-II molecules can be placed in a unique orientation in the complex so that all experimental data, and hydrophilic-hydrophobic and electrostatic interactions are satisfied. The resulting model is presented in Figure 7. As can be seen from Figure 7, Phe48 of IGF-II could be docked on the hydrophobic patch of mini-IGFBP-5. The hydrophilic and acidic Glu6 of IGF-II interacts with the basic Lys68 of mini-IGBFP-5. Thus, the hydrophobichydrophilic fit is strikingly complementary in the complex, in agreement with the experimental tight nanomolar binding between mini-IGFBP-5 and IGF-II. The model may 
be further improved if some conformational rearrangements of the N-terminus of IGF-II and the variable loop between residues 62 and 69 of mini-IGFBP-5 were allowed.

In contrast to the conserved hydrophobic patch of the IGFBPs, the variable loop between residues 62 and 69 is less conserved and may be responsible for the variations of affinities to IGFs observed among the IGFBPs. Interestingly, the basic Lys68 of IGFBP-5 is conserved also in IGFBP-3 and IGFBP-4 (Lys, Arg, respectively). The nature of these residues differs significantly from the hydrophobic or neutral residues of IGFBP-1,-2 and -6 (Gln, Leu and Ala, respectively). This may explain their decreased affinities to IGFs, since according to our model of the IGF-IGFBP complex, acidic Glu6 of IGF-II binds to this region of the IGF-binding protein (Figure 7).

Degradation of IGFBPs by specific IGFBP proteases is known to occur under a variety of physiological and pathophysiological conditions (Rajaram et al., 1997) and therefore the interaction of IGFBP-5 and its fragments with the IGF-receptor binding and signalling was investigated in more detail. Ligand binding assays using radiolabelled IGFs clearly demonstrated that the full-length IGFBP-5 and the N-terminal fragments are able to inhibit the binding of IGFs to the receptor. In contrast to the relative affinities determined by biosensor measurements, lower concentrations of IGFBP-5 than theoretically expected were sufficient to interfere with receptor binding and indicate a higher affinity of the complex in solution, as reported in other studies using radiolabelled binding partners (Kiefer et al., 1992; Loddick et al., 1998). In addition to the different experimental conditions of these assays (temperature, buffers, concentrations) the use of an immobilized and thereby chemically modified ligand in the biosensor method may result in reduced apparent affinities, especially for full-length IGFBP-5. Similar differences between biosensor and solution binding assays were also reported for IGFBP-3 and the apparent affinities determined by the BIAcore method were dependent on the experimental conditions and the method of data analysis for determining the kinetic constants (Sommer et al., 1993; Heding et al., 1996). It also should be noted that the comparison of the IGF-II-IGF-IR-IGFBP-5 and IGF-IIIGFBP-5 complexes is further complicated by the fact that IGFs appear to undergo a conformational change on binding to their receptors (Gill et al., 1996; Jansson et al., 1997).

Upon binding of IGFs to the IGF-IR, the intracellular part of the receptor undergoes autophosphorylation, which is a prerequisite for all known IGF-mediated biological actions. Therefore we used the IGF-mediated receptor autophosphorylation as a further method to investigate how the biological action of IGFs is modulated by IGFBP-5 and its fragments. Surprisingly, intact IGFBP-5 inhibits IGF-stimulated autophosphorylation of the receptor very efficiently and complete inhibition is achieved when IGFBP-5 is in excess of IGFs. The $\mathrm{IC}_{50}$ values of IGFBP-5 in this experiment are 100-fold higher than in the ligand-binding assay because the cell number and IGF concentration had to be increased to allow detection of the autophosphorylation of the receptor. In the ligandbinding assay a 1000-fold higher concentration of fragments than IGFBP-5 was necessary to inhibit the binding of IGFs to the cell but we were not able to apply equivalent increased concentrations of fragments in the receptor stimulation assay. Therefore, we cannot completely exclude the possibility that inhibition of receptor stimulation might occur at higher concentrations of the fragments.

The receptor-stimulation assay and the ligand-binding assay clearly demonstrate that intact IGFBP-5 inhibits the biological activity of IGFs. N-terminal fragments are still able to bind IGFs with moderate affinities but they are only able to inhibit receptor binding at unphysiologically high concentrations. The affinity of the fragments is much lower than the affinity of IGF-IR for IGFs and therefore they are not able to compete with receptor stimulation under physiological conditions. Accordingly, cleavage of IGFBP-5 by proteases will result in strongly reduced affinities of the fragments and thereby increased levels of free IGFs which are able to stimulate the receptor signalling.

The observation that a weak inhibitory potency of the $\mathrm{N}$-terminal fragments of IGFBP-5 does not reflect their high affinity for IGF-II clearly indicates that the C-terminal domain of IGFBP-5 has the capacity to enhance the affinity of the native protein to inhibit IGF activation of the receptor. Since no primary binding site appears to exist in the C-terminal domain, the higher affinity of the full-length protein may result either from low-affinity binding sites within the $\mathrm{C}$-terminal part of the protein (in a similar fashion to that found in IGFBP-4; Qin et al., 1998) or from a structural change of the N-terminal domain resulting in an increased affinity and inhibition of receptor binding. However, conformational changes within the N-terminal domain are unlikely because of the rigid and compact mini-IGFBP-5 structure (stabilized, for example, by covalent disulfide bonds, also unchanged in the $10 \mathrm{kDa}$ fragment). Figure $3 \mathrm{~A}$ indicates that incomplete inhibition of receptor binding is observed for the fragments, especially in the case of mini-IGFBP-5, where the inhibition curve does not drop all the way to zero even at high concentrations. Therefore, it appears that IGF-II still binds to the receptor even when complexed to the truncated IGFBP-5 fragments, which implies that the binding of IGF-II to its receptor is sterically hindered by the C-terminal domain of the much larger full-length IGFBP5. Additionally, it should be remembered that IGFs appear to undergo a conformational change on binding to their receptors (Gill et al., 1996; Jansson et al., 1997).

The inhibition of the stimulation of the IGF receptor by IGF-I in the presence of full-length IGFBP-5 and the strongly reduced inhibitory potency of the N-terminal fragments of IGFBP-5 may account for contradictory results reported in the literature on the activity of IGFBPs in different assay systems (Gill et al., 1997; Higo et al., 1997; Yeh et al., 1997). The stimulation of the IGF-I activity by IGFBP-5 may be caused either by targeting IGF-I to the receptor-containing cell surface, by an IGFindependent effect of the binding protein as shown for fragments of IGFBP-3 (Gill et al., 1997), or by a fast degradation during the incubation period in cell culture. On the other hand, the inhibitory effect of IGFBP-5 on the growth of carcinoma C33A cells (Higo et al., 1997) and on the induction of alkaline phosphatase in fetal rat calvarial cells by OP-1 (Yeh et al., 1997) clearly 
demonstrates the ability of IGFBP-5 to act as an inhibitor of cell proliferation or differentiation.

\section{Materials and methods}

\section{Cloning, protein expression and purification}

For subcloning of mini-IGFBP-5 (residues 40-92 of IGFBP-5) and the His-tag $10 \mathrm{kDa}$ IGFBP-5 domain (residues 1-104) into the BamHI and PstI restrictions sites of the pQE30-vector (Qiagen, Hilden, Germany) in-frame to a His-tag, two sets of the following oligonucleotides were designed for amplification of cDNA by PCR : 5'mini-IGFBP-5: gatggatccetggttccgegtggttcagccCTGGCCCTGGCCGAGGGGCAG; 3'mini-IGFBP-5: gatctggacttaGATCTTGACTTGCTCGCGGTA; 5'10-kDa-IGFBP5: gcgggatccatGCAAGGATGATTTGTGCAC; 3'10-kDa-IGFBP5: gcgctgcagttaGGTGGTGGGCTCCTCGTG Restrictions sites, a stop codon, and in the case of the mini-construct, 21 bases encoding an $\mathrm{N}$-terminal thrombin cleavage site were introduced using overhangs shown in small letters. Vector $(0.2 \mu \mathrm{g})$ containing the complete sequence of IGFBP-5 was used as a template. Conditions for the PCR reaction were as follows: polymerase Vent (National Biolabs, UK); $2 \mathrm{mM} \mathrm{MgSO}_{4}$; $\left(92^{\circ} \mathrm{C}\right.$ for $60 \mathrm{~s}, 62^{\circ} \mathrm{C}$ for $60 \mathrm{~s}, 72^{\circ} \mathrm{C}$ for $\left.40 \mathrm{~s}\right) \times 35$ for mini-IGFBP-5; and $\left(92^{\circ} \mathrm{C}\right.$ for $60 \mathrm{~s}, 60^{\circ} \mathrm{C}$ for $60 \mathrm{~s}, 72^{\circ} \mathrm{C}$ for $\left.40 \mathrm{~s}\right) \times 35$ for $10 \mathrm{kDa}$ IGFBP-5. Standard procedures were used for construction and verification of vectors pQE30 (mini-IGFBP-5) and pQE30 (Histag10 kDa IGFBP-5) which were transformed finally into E.coli strain Bl21(DE3) (Novagen, Canada) for overexpression of tag-miniIGFBP-5 which encodes the following amino acid sequence mrgshhhhhsglvprGSALA..SYREQVKI and $10 \mathrm{kDa}$ IGFBP-5 which encodes for $m r g s h h h h h h s g$ MVLL...KIERDS. Amino acids of the Histag, including the thrombin-cleavage site (underlined), are in italics. MiniIGFBP-5 and $10 \mathrm{kDa}$ IGFBP-5 after cleavage by thrombin comprises the amino acid sequence denoted in capital letters.

Expression was performed for both constructs at $37^{\circ} \mathrm{C}$ in shaking cultures at 300 r.p.m. Ampicillin ( $100 \mu \mathrm{g}$ per 11 culture) was used as the selection antibiotic and expression was induced by $1 \mathrm{mM}$ IPTG at a cell density of $\mathrm{OD}_{600}=0.8$. Cells were harvested after $4 \mathrm{~h}$ by centrifugation. For protonated samples standard LB-media were used. Uniformly ${ }^{15} \mathrm{~N}$-labelled and ${ }^{13} \mathrm{C} /{ }^{15} \mathrm{~N}$ - doubly labelled mini-IGFBP-5 samples were prepared in a M9-minimal medium containing $1 \mathrm{~g} / \mathrm{l}$

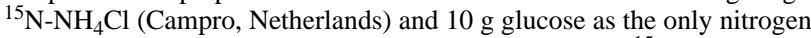
and carbon source (Muchmore et al., 1989) or $1 \mathrm{~g} / \mathrm{l}^{15} \mathrm{~N}-\mathrm{NH}_{4} \mathrm{Cl}$ and $2 \mathrm{~g} /{ }^{13} \mathrm{C}_{6}$-glucose, supplemented with minerals and cofactors (Hoffman and Spicer, 1991). For ${ }^{15} \mathrm{~N}$ amino acid selective labelling, the minimal medium $\left({ }^{14} \mathrm{~N}\right)$ was enriched with unlabelled amino acids and the double amount of the ${ }^{15} \mathrm{~N}$-labelled amino acid (Muchmore et al., 1989). Selectively labelled mini-IGFBP-5 in ${ }^{15} \mathrm{~N}$ glycine/serine, glycine/serine/ cysteine, alanine/valine and leucine were prepared.

\section{Purification of mini-IGFBP-5 and the His-tag $10 \mathrm{kDa}$ IGFBP-5}

The following instructions are referred to a cell material of a 11 culture containing $\sim 5 \mathrm{mg}$ mini-IGFBP-5 or $10 \mathrm{mg} 10 \mathrm{kDa}$ IGFBP-5 (1-104). The pelleted cells were resuspended in $20 \mathrm{ml}$ of buffer A $(6 \mathrm{M}$ guanidinium chloride, $100 \mathrm{mM} \mathrm{Na} \mathrm{PO}_{4}, 10 \mathrm{mM}$ Tris, $10 \mathrm{mM} \beta$ mercaptoethanol $\mathrm{pH} \mathrm{8.0)}$ and stirred for $1 \mathrm{~h}$ to lyse the cells. This solution was centrifuged for $1 \mathrm{~h}$ at $60000 \mathrm{~g}$, the supernatant was loaded on a $5 \mathrm{ml} \mathrm{Ni-NTA}$ (Qiagen) column, washed with $\sim 100 \mathrm{ml}$ buffer A, $\sim 100 \mathrm{ml}$ buffer B (buffer A at pH 6.0), and the protein eluted using a $100 \mathrm{ml}$ gradient of buffer $\mathrm{B}$ and buffer $\mathrm{C}$ (6 M guanidinium chloride, $10 \mathrm{mM} \beta$-mercaptoethanol, $100 \mathrm{mM}$ acetate, $\mathrm{pH} 4.5$ ). Fractions containing mini-IGFBP- 5 were pooled, and $0.2 \mathrm{~g}$ of DDT was added to reduce every cysteine bridge. The volume was reduced to $1 \mathrm{ml}$ by ultrafiltration (Amicon) and dialysed against buffer $\mathrm{D}(6 \mathrm{M}$ guanidinium chloride $\mathrm{pH} 3.0$ ) to remove DDT before diluting into $25 \mathrm{ml}$ of the refolding buffer $\mathrm{E}(0.2 \mathrm{M}$ arginine, $1 \mathrm{mM}$ EDTA, $1 \mathrm{mM}$ reduced glutathione, $1 \mathrm{mM}$ oxidized glutathione, $100 \mathrm{mM}$ Tris $\mathrm{pH}$ 8.2). After $14 \mathrm{~h}$ at $4^{\circ} \mathrm{C}$ tag-mini-IGFBP-5 was completely refolded (checked by reverse-phased chromatography; data not shown). The concentrated solution was dialysed against buffer $\mathrm{F}(60 \mathrm{mM} \mathrm{NaCl}, 60 \mathrm{mM} \mathrm{KCl}$, $2.5 \mathrm{mM} \mathrm{CaCl}_{2}, 50 \mathrm{mM}$ Tris $\mathrm{pH} 8.0$ ) in order to cut off the His-tag by 20 units of thrombin (T3010, Sigma, Germany) within $12 \mathrm{~h}$ at room temperature. The samples were then dialysed against buffer $\mathrm{G}(50 \mathrm{mM}$ Tris pH 8.0) and loaded on an anion exchange column (DE 52, Whatman). The flow-through contained the pure protein, mini-IGFBP-5. A final gel filtration was performed on Superdex75 (Pharmacia) in buffer H (100 mM $\mathrm{Na}_{2} \mathrm{PO}_{4}, 200 \mathrm{mM} \mathrm{NaCl} \mathrm{pH} \mathrm{5.0).}$
For the His-tag $10 \mathrm{kDa}$ IGFBP-5, the purification and refolding was identical except that the thrombin proteolysis was not carried out. The NMR samples were measured at $\mathrm{pH} 4.5$ in $20 \mathrm{mM}$ phosphate buffer, $50 \mathrm{mM} \mathrm{NaCl}, 1 \mathrm{mM}$ EDTA and $10 \% \mathrm{D}_{2} \mathrm{O}$.

\section{Proteolytic digest of IGFBP-5}

Recombinant human IGFBP-5 was produced in E.coli as described by Mohan et al. (1995). Proteolytic fragments of IGFBP-5 were produced by incubation of IGFBP-5 with endoproteinase Asp N (Boehringer Mannheim) $\left(200: 1\right.$; w/w) in $20 \mathrm{mM} \mathrm{Na} 2 \mathrm{PO}_{4} \mathrm{pH} 7.0$ for $4 \mathrm{~h}$ at $26^{\circ} \mathrm{C}$. Fragments were isolated after addition of urea (up to $7 \mathrm{M}$ ) by separation using S-Sepharose (Pharmacia). The C-terminal $17 \mathrm{kDa}$ fragment was eluted with a gradient from $0-0.5 \mathrm{M} \mathrm{NaCl}$ and dialysed against phosphatebuffered saline (PBS). The 10 and $4 \mathrm{kDa}$ fragments, which passed through the column, were separated by hydroxyapatite chromatography (Macro Prep, Bio-Rad).

\section{BIAcore analysis}

BIAcore 2000, Sensor Chip SA and HBS were obtained from BIAcore $\mathrm{AB}$ (Uppsala, Sweden). All experiments were performed at $25^{\circ} \mathrm{C}$ and HBS was used as a running buffer and for the dilution of ligands and analytes. Biotinylated IGF-I was immobilized at a concentration of 5 and $10 \mathrm{nM}$ in HBS at a flow rate of $5 \mu \mathrm{l} / \mathrm{min}$ to the streptavidin-coated sensor chip resulting in signals of 40 and 110 resonance units (RU). Biotinylated IGF-II was immobilized at a concentration of $5 \mathrm{nM}$ in HBS resulting in a signal of $20 \mathrm{RU}$. An empty flow cell was used as control for unspecific binding and bulk effects. The low ligand concentration was necessary to limit mass-transport limitations and rebinding. For the same reason all kinetic experiments were performed at the highest possible flow rate of $100 \mu \mathrm{l} / \mathrm{min}$. Each solution (IGFBP-5, mini-IGFBP5 and the N-terminal $10 \mathrm{kDa}$ fragment) was injected at four concentrations $(250,50,10$ and $2 \mathrm{nM})$. Each sample was injected for 2 min followed by dissociation in buffer flow for $4 \mathrm{~min}$. After the dissociation phase the sensor chip was regenerated by injection of $10 \mu \mathrm{l}$ of $100 \mathrm{mM} \mathrm{HCl}$ at a flow rate of $5 \mu \mathrm{l} / \mathrm{min}$. The kinetic parameters were calculated using the BIAevaluation 3.0 software (BIAcore AB). After subtraction of the blank sensorgram the kinetic rate constants were calculated from a general fit of an overlay of the sensorgrams of all concentration of one analyte using the method called ' $1: 1$ binding with mass transfer'. IGF-I and IGF-II were biotinylated with a 5-fold molar excess of D-biotinyl$\varepsilon$-aminocaproic acid- $N$-hydroxysuccinimide ester using the reagents and the operation instructions of the Biotin Protein Labelling Kit (Boehringer Mannheim $\mathrm{GmbH}$ ). After blocking with lysine, the reaction mixture was dialysed against $50 \mathrm{mM} \mathrm{Na}_{2} \mathrm{PO}_{4}, 50 \mathrm{mM} \mathrm{NaCl} \mathrm{pH} \mathrm{7.5.}$

\section{Ligand binding}

NIH 3T3 cells stably expressing human IGF-IR (kindly provided by Axel Ullrich) were grown in culture dishes in Dulbecco's modified Eagle's medium (DMEM) containing 10\% fetal calf serum. Cells were washed carefully with PBS and incubated with $5 \mathrm{ml}$ of $50 \mathrm{mM}$ EDTA in PBS for $45 \mathrm{~min}$. Cells were removed from the plate, washed once with PBS and once with binding buffer $(100 \mathrm{mM}$ HEPES $\mathrm{pH}$ 7.6, $120 \mathrm{mM} \mathrm{NaCl}, 5 \mathrm{mM} \mathrm{KCl}, 1.2 \mathrm{mM} \mathrm{MgSO}_{4}, 1 \mathrm{mM}$ EDTA, $10 \mathrm{mM}$ glucose, $15 \mathrm{mM}$ sodium acetate, $1 \%$ dialysed BSA), and resuspended in binding buffer to determine the cell number. Then $5 \mathrm{pM}{ }^{125}$ I-IGF-I or $5 \mathrm{pM}{ }^{125}$ I-IGF-II (Amersham) was preincubated with increasing concentrations of the different IGF-binding proteins from 0 to $1 \times 10^{-6}$ $\mathrm{M}$ at $4^{\circ} \mathrm{C}$ for $1 \mathrm{~h}$ and then added to $400 \mu \mathrm{l}$ of the cell suspension corresponding to $2 \times 10^{5}$ cells to give a total volume of $500 \mu$ l. After $12 \mathrm{~h}$ incubation at $4^{\circ} \mathrm{C}$, cells were washed with binding buffer (at $4^{\circ} \mathrm{C}$ ). Free hormone was removed by repeated centrifugation and resuspension in the binding buffer. The ${ }^{125} \mathrm{I}$ radioactivity bound to the cells was determined in a $\gamma$-counter.

\section{Receptor phosphorylation}

Confluent monolayers of the NIH 3T3 cells stably expressing human IGF-IR in $3.5 \mathrm{~cm}$ dishes were starved in DMEM containing $0.5 \%$ dialysed fetal calf serum. After $48 \mathrm{~h}$, cells were incubated without any hormone or with $5 \times 10^{-9} \mathrm{M}$ IGF-I or $1 \times 10^{-8} \mathrm{M}$ IGF-II; each sample was preincubated with increasing concentrations of different IGF-binding proteins from 0 to $1 \times 10^{-6} \mathrm{M}$ at room temperature for $1 \mathrm{~h}$. After a $10 \mathrm{~min}$ stimulation at $37^{\circ} \mathrm{C}$, the medium was removed and cells were lysed with $250 \mu \mathrm{l}$ of lysing buffer (20 mM HEPES pH 7.5, $150 \mathrm{mM}$ $\mathrm{NaCl}, 10 \%$ glycerol, $1 \%$ NP-40, $1.5 \mathrm{mM} \mathrm{MgCl}, 1 \mathrm{mM}$ EGTA), $10 \mathrm{mM}$ sodium orthovanadate, and protease inhibitor cocktail Complete (Boehringer Mannheim) for $10 \mathrm{~min}$ on ice. Subsequently, cells were scraped off the plate and the insoluble material was separated by 
centrifugation for $20 \mathrm{~min}$ at $4^{\circ} \mathrm{C}$. The protein concentration of the supernatant was determined using the BCA kit from Pierce according to the manufacturer's instructions. Equal protein concentration was incubated with the SDS sample buffer $(63 \mathrm{mM}$ Tris- $\mathrm{HCl} \mathrm{pH} 6.8,3 \%$ SDS, $10 \%$ glycerol, $0.05 \%$ bromophenolblue, $100 \mathrm{mM}$ DTT), boiled for 5 min and loaded on a 7.5\% SDS-polyacrylamide gel. After electrophoresis the proteins were transferred on a nitrocellulose membrane which first was blocked for $1 \mathrm{~h}$ with the $3 \%$ BSA containing phosphatebuffered saline-Tween (PBST), then incubated overnight with $1 \mu \mathrm{g} /$ $\mathrm{ml}$ monoclonal anti-phosphotyrosine antibody 3-365-10 (Boehringer Mannheim) in PBST that contained 3\% BSA. Unbound antibody was removed by extensive washing. The blot was then incubated with 1:10 000 diluted anti-mouse IgG-specific antibody conjugated with horse radish peroxidase (Boehringer Mannheim). The immunoblot was developed using the ECL kit from Amersham.

\section{NMR spectroscopy}

NMR experiments were carried out at $304 \mathrm{~K}$ on Bruker AMX 500, DRX 600 and DMX 750 spectrometers. All spectrometers were equipped with triple resonance $\left({ }^{1} \mathrm{H},{ }^{13} \mathrm{C},{ }^{15} \mathrm{~N}\right)$ probeheads and pulsed-field gradient (PFG) accessories. Triple resonance [CBCA(CO)NH; Grzesiek and Bax, 1992a; CT-HNCA, CT-HNCO Grzesiek and Bax, 1992b], 3D ${ }^{1} \mathrm{H}_{-}{ }^{15} \mathrm{~N}$ NOESY-HSQC, 3D ${ }^{1} \mathrm{H}_{-}{ }^{15} \mathrm{~N}$ TOCSY-HSQC, 3D ${ }^{1} \mathrm{H}_{-}{ }^{13} \mathrm{C}$ NOESY-HSQC and 3D HCCH-TOCSY experiments (Bax and Grzesiek, 1993; Kay et al., 1993; Edison et al., 1994) were recorded for both the uncomplexed and the IGF-II-complexed form of mini-IGFBP-5. For non-selective inversion of ${ }^{13} \mathrm{C}$ longitudinal magnetization hard power, square pulses were replaced by adiabatic pulses (Silver et al., 1984; Kupce and Freeman, 1995). Isotropic mixing (Braunschweiler and Ernst, 1983) was performed with DIPSI-2 and DIPSI-3 spin-lock sequences (Shaka et al., 1988). Water suppression in experiments recorded on samples in $\mathrm{H}_{2} \mathrm{O}$ was achieved by incorporation of a WATERGATE sequence (Sklenar et al., 1993) into the various pulse sequences. Residual water in experiments measured on samples in $\mathrm{D}_{2} \mathrm{O}$ was removed by application of a weak presaturation field of $15 \mathrm{~Hz}$. Quadrature detection in all indirectly detected dimensions was obtained through STATES-TPPI phase cycling (Marion et al., 1989). Triple resonance experiments, 2D $\operatorname{TOCSY}\left(\tau_{\mathrm{m}}=62 \mathrm{~ms}\right), 3 \mathrm{D}{ }^{1} \mathrm{H}_{-}{ }^{15} \mathrm{~N}$ TOCSY-HSQC $\left(\tau_{\mathrm{m}}=62 \mathrm{~ms}\right)$, long mixing time $2 \mathrm{D}$ NOESY $\left(\tau_{\mathrm{m}}=120 \mathrm{~ms}\right)$ and long mixing time $3 \mathrm{D}{ }^{1} \mathrm{H}$ ${ }^{15} \mathrm{~N}$ NOESY-HSQC $\left(\tau_{\mathrm{m}}=120 \mathrm{~ms}\right)$ experiments in $\mathrm{H}_{2} \mathrm{O}$ were recorded as water flip-back versions employing either carefully selected pulse phases (Jahnke et al., 1995; Stonehouse et al., 1995), selective pulses on water (Lippens et al., 1995; Dhalluin et al., 1996) or constructive radiation damping (Talluri and Wagner, 1996). The $3 \mathrm{D}{ }^{1} \mathrm{H}^{15} \mathrm{~N}$ TOCSYHSQC $\left(\tau_{\mathrm{m}}=62 \mathrm{~ms}\right)$ experiment was modified according to the $2 \mathrm{D}$ water flip-back TOCSY for achieving minimal saturation of water (Dhalluin et al., 1996). In short mixing time 2D NOESY experiments zero-quantum coherence contributions were reduced by varying the mixing time randomly for every individual transient of each FID (Hull, 1994). Side-chain resonances were assigned using 2D NOESY $\left(\tau_{\mathrm{m}}=\right.$ $120 \mathrm{~ms})$ in $\mathrm{D}_{2} \mathrm{O}, 3 \mathrm{D}{ }^{15} \mathrm{~N}$-edited TOCSY $\left(\tau_{\mathrm{m}}=62 \mathrm{~ms}\right)$ and 3D HCCHTOCSY $\left(\tau_{\mathrm{m}}=19 \mathrm{~ms}\right)$ experiments. Stereospecific assignments were obtained from a combination of 2D DQF-COSY (Rance et al., 1983) in $\mathrm{D}_{2} \mathrm{O}$, short mixing time 2D NOESY in $\mathrm{H}_{2} \mathrm{O}$ and $\mathrm{D}_{2} \mathrm{O}\left(\tau_{\mathrm{m}}=14 \mathrm{~ms} \pm\right.$ $4 \mathrm{~ms}), 2 \mathrm{D}{ }^{1} \mathrm{H}^{\mathrm{N}}{ }^{15} \mathrm{~N}-\left[{ }^{13} \mathrm{C}^{\gamma}\right]$ difference HSQC (Hu and Bax, 1997a), 3D $\mathrm{HN}(\mathrm{CO}) \mathrm{C}$ (Hu and Bax, 1997b) and 2D ${ }^{13} \mathrm{C}^{\prime}-\left[{ }^{13} \mathrm{C}^{\gamma[\text { aromatics }]}\right]$ spin-echo difference together with $2 \mathrm{D}{ }^{15} \mathrm{~N}-\left[{ }^{13} \mathrm{C}\right.$ [aromatics] $]$ spin-echo difference ${ }^{1} \mathrm{H}^{\mathrm{N}}{ }_{-}^{15} \mathrm{~N}$ HSQC experiments (Hu et al., 1997). $\chi^{1}$ angles in valine, isoleucine, and threonine residues were determined by $2 \mathrm{D}$ spin-echo difference CT-HSQC and 2D long-range ${ }^{13} \mathrm{C}-{ }^{13} \mathrm{C}$ correlation experiments (Bax et al., 1994). Side-chain amide protons of asparagine and glutamine residues were assigned stereospecifically with a $2 \mathrm{D} \mathrm{H}_{2} \mathrm{NCO}-\mathrm{E}$.COSY (Löhr and Rüterjans, 1997). Presence of multiple conformations was ruled out by a combination of short mixing time 2D NOESY $\left(\tau_{\mathrm{m}}=14\right.$ $\mathrm{ms} \pm 4 \mathrm{~ms}), 2 \mathrm{D}$ TOCSY $\left(\tau_{\mathrm{m}}=62 \mathrm{~ms}\right)$ and 2D ROESY (Brown and Farmer, 1989) $\left(\tau_{\mathrm{m}}=50 \mathrm{~ms}\right)$ spectra in $\mathrm{D}_{2} \mathrm{O}$. The state of oligomerization was investigated with two $2 \mathrm{D}{ }^{15} \mathrm{~N}$ double-half-filtered NOESYs (Otting and Wüthrich, 1990) $\left(\tau_{\mathrm{m}}=120 \mathrm{~ms}\right)$ at pHs 4.5 and 3.9 in $\mathrm{H}_{2} \mathrm{O}$ and with a $2 \mathrm{D}{ }^{13} \mathrm{C}$ double-half-filtered $\operatorname{NOESY}\left(\tau_{\mathrm{m}}=120 \mathrm{~ms}\right)$ experiment utilizing optimized WURST inversion pulses for suppression of signals from ${ }^{13} \mathrm{C}$-labelled molecules in $\mathrm{D}_{2} \mathrm{O}$ (Folmer et al., 1995; Zwahlen et al., 1997). The $2 \mathrm{D}{ }^{15} \mathrm{~N}$ double-half-filtered NOESY sequence was transformed into a water flip-back version by incorporation of selective pulses on water. The complexation of mini-IGFBP-5 with IGF-II was investigated with $3 \mathrm{D}{ }^{13} \mathrm{C} \mathrm{F}_{1}$-filtered, F $F_{3}$-edited NOESY-HSQCs $\left(\tau_{\mathrm{m}}=\right.$ $150 \mathrm{~ms}$ ) in $\mathrm{H}_{2} \mathrm{O}$ and $\mathrm{D}_{2} \mathrm{O}$ (Zwahlen et al., 1997). 2D ${ }^{1} \mathrm{H}_{-}{ }^{15} \mathrm{~N}$ HSQC spectra with reduced signal loss due to the fast chemical exchange were recorded using procedures described by Mori et al. (1995). Exchange rates of ${ }^{1} \mathrm{H}-{ }^{15} \mathrm{~N}$-bound protons were measured by recording a series of 2D ${ }^{1} \mathrm{H}-{ }^{15} \mathrm{~N}$ HSQC spectra at 25 and $35 \mathrm{~min} ; 1,2,4$ and $10 \mathrm{~h} ; 1$ and 3 days, 1 week and 1 month after dissolving the protein in $\mathrm{D}_{2} \mathrm{O}$. All 3D spectra were processed and evaluated with the software CC-NMR (Cieslar et al., 1993). Resolution in the indirect dimensions was increased by linear prediction and zero-filling (Edison et al., 1994). The ${ }^{1} \mathrm{H}_{-}{ }^{15} \mathrm{~N}$ heteronuclear NOE measurements were carried out using the pulse sequence of Farrow et al. (1994). Saturation of the amide protons in the heteronuclear NOE experiment was achieved by the application of a series of $120^{\circ}$ pulses prior to the experiment (Farrow et al., 1994). Intensities of the cross peaks in the NOE spectrum were obtained from the peak heights.

\section{Assignment and structure calculation}

Assignment, data-handling and control of X-PLOR-calculations (Brünger, 1993; Brünger and Nilges, 1993) were performed using our software NMRscout, which is based on CC-NMR (Cieslar et al., 1993). NOEs were derived from the 2D NOESY spectra in $\mathrm{H}_{2} \mathrm{O}$ and $\mathrm{D}_{2} \mathrm{O}$, from the ${ }^{15} \mathrm{~N}$-edited and the ${ }^{13} \mathrm{C}$-edited NOESY spectra. Peak heights were used for quantification of peak intensities. Four classes of NOEs were distinguished: $4.2 \AA$ for a weak, $3.5 \AA$ for a medium, $2.8 \AA$ for a medium-strong and $2.3 \AA$ for a strong NOE-signal. Sequential $\mathrm{H}^{\alpha}(\mathrm{i})$ $\mathrm{H}^{\mathrm{N}}(\mathrm{i}+1)$ signals within $\beta$-elements were rated as strong NOEs; other NOE intensities were then ascribed according to this internal calibration. The upper and lower boundaries (in parentheses) for these distance restraints were set to $0.8 \AA(0.6), 0.5 \AA(0.5), 0.4 \AA(0.4)$ and $0.4 \AA$ $(0.4)$, respectively. All protons were explicitly defined in the dynamic simulated annealing calculations; in some cases, however, additional terms were added to the upper bounds as a pseudoatom correction (Wüthrich, 1986).

The distance constraints were then supplemented with $44 \phi$ torsion angle constraints derived from $\mathrm{HNHA}, \mathrm{HN}(\mathrm{CO}) \mathrm{CO}$ and $\mathrm{HN}(\mathrm{CO}) \mathrm{C}$ experiments (Vuister and Bax, 1993; $\mathrm{Hu}$ and $\mathrm{Bax}, 1996 ; \mathrm{Hu}$ and $\mathrm{Bax}$, 1997b). At the final stage, two $\omega$ angles for the trans-peptide bond of the X-Pro residues, together with $34 \chi^{1}$ restraints were added. Structure calculations were performed using standard protocols (Holak et al., 1989) for simulated annealing and distance geometry constraint methods implemented in the program X-PLOR.

\section{Binding of IGF-II to IGFBP-5}

The ${ }^{1} \mathrm{H}_{-}{ }^{15} \mathrm{~N}$ - and ${ }^{1} \mathrm{H}_{-}{ }^{13} \mathrm{C}-\mathrm{HSQC}$ spectra of mini-IGFBP-5 complexed to IGF-II and IGF-I were assigned independently on the basis of two sets of CT-HNCA, CBCA(CO)NH, CT-HNCO and ${ }^{15} \mathrm{~N}$-separated NOESYHSQC spectra. HSQC spectra were successively recorded for mixtures of mini-IGFBP-5 and IGFs with IGF concentrations of 0, 10, 20, 40, $60,80,100$ and $120 \%$ relative to mini-IGFBP-5. All IGF-induced shifts $\boldsymbol{S}(\boldsymbol{i})_{\text {atom }}$ of one atom-type (for example, ${ }^{1} \mathrm{H}$ backbone and side-chain proton atoms) and residue $i$ were combined and averaged to $S(i)_{H}, S(i)_{C}$ and $\boldsymbol{S}(\boldsymbol{i})_{N}$. Different sensitivities of chemical shifts of proton, nitrogen and carbon atoms were considered by introducing scaling factors $f_{\text {Atom }}$ with $f_{H}=1, f_{N}=0.2$ and $f_{C}=0.5$ so that the scaled shift $\operatorname{SN}(i)_{\text {atom }}$ was calculated as $\boldsymbol{S N}(\boldsymbol{i})_{\text {atom }}=\boldsymbol{f}_{\text {Atom }} \times \boldsymbol{S}(\boldsymbol{i})_{\text {atom }}$. Combinations of shifts

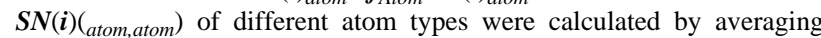
$\boldsymbol{S} \boldsymbol{N}_{\text {atom }}\left[\right.$ e.g. $\boldsymbol{S N}(\boldsymbol{i})\left(_{H C}\right)=\left(\boldsymbol{S N}(\boldsymbol{i})_{H} \times \boldsymbol{w}_{\boldsymbol{H}}+\boldsymbol{S N}(\boldsymbol{i})_{C} \times \boldsymbol{w}_{\boldsymbol{c}}\right) /\left(\boldsymbol{w}_{\boldsymbol{H}}+\boldsymbol{w}_{\boldsymbol{c}}\right)$, where $\boldsymbol{w}_{\text {atom }}$ is a weighting factor, $\boldsymbol{w}_{\boldsymbol{H}}=\boldsymbol{w}_{\boldsymbol{c}}=2, \boldsymbol{w}_{N}=1$; see Figure 6]. The error in chemical shift is estimated to be 0.01 p.p.m.

The docking experiments for the model of the IGF-II and miniIGBP-5 complex were carried out with the Insight II program using the coordinates of IGF-II found in entry 1IGL (PDB data bank) (Torres et al., 1995). Twenty structures for each IGF-II and mini-IGFBP-5 have been docked manually with each other assuming the binding sites determined experimentally (see Results). The resulting complexes were subjected to energy minimization with the Discover programme. Thirty lowest energy structures that were chosen had their final energies close to each other $(93 \pm 12 \mathrm{kcal} / \mathrm{mol})$. Figure 7 shows the model for the lowest energy calculation.

\section{Supplementary material}

Supplementary material available from the authors consists of a table with the ${ }^{1} \mathrm{H},{ }^{13} \mathrm{C}$ and ${ }^{15} \mathrm{~N}$ chemical shifts of mini-IGFBP-5. The coordinates of mini-IGFBP-5 together with a complete list of NOE, hydrogen-bond and torsion angle constraints have been deposited in the Brookhaven Data Bank. 


\section{Acknowledgements}

We thank Professor Axel Ullrich for providing NIH 3T3 cells expressing IGF-IR, Drs M.L.Hagmann and M.Wozny for sequence and mass analyses, K.Tandler, H.Rabenseifner, M.Brügner and T.Weinschenk for excellent technical assistance, P.Mühlhahn for assistance during structure elucidation and R.Engh for discussion.

\section{References}

Andress,D.L., Loop,S.M., Zapf,J. and Kiefer,M.C. (1993) Carboxytruncated insulin-like growth factor binding protein-5 stimulates mitogenesis in osteoblast-like cells. Biochem. Biophys. Res. Commun., $195,25-30$.

Arai,T., Clarke,J., Parker,A., Busby,W.,Jr, Nam,T. and Clemmons,D.R. (1996) Substitution of specific amino acids in insulin-like growth factor (IGF) binding protein 5 alters heparin binding and its change in affinity for IGF-I response to heparin. J. Biol. Chem., 271, 6099-6106.

Bach,L.A., Hsieh,S., Sakano,K., Fujiwara,H., Perdue,J.F. and Rechler,M.M. (1993) Binding of mutants of human insulin-like growth factor II to insulin-like growth factor binding proteins 1-6. J. Biol. Chem., 268, 9246-9254.

Bautista,C.M., Baylink,D.J. and Mohan,S. (1991) Isolation of a novel insulin-like growth factor (IGF) binding protein from human bone: a potential candidate for fixing IGF-II in human bone. Biochem. Biophys. Res. Commun., 176, 756-763.

Bax,A. and Grzesiek,S. (1993) Methodological advances on protein. Acc. Chem. Res., 26, 131-138.

Bax,A., Vuister,G.W., Grzesiek,S., Delaglio,F., Wang,A.C., Tschudin,R. and Zhu,G. (1994) Measurement of homonuclear and heteronuclear J-couplings from quantitative J-correlation. Methods Enzymol., 239, 79-105.

Braunschweiler,L. and Ernst,R.R. (1983) Coherence transfer by isotropic mixing: Application to proton correlation spectroscopy. J. Magn. Reson., 53, 521-528.

Brown,L.R.,and Farmer,B.T. (1989) Rotating frame nuclear Overhauser effect. Methods Enzymol., 176, 199-216.

Brünger,A.T. (1993) X-PLOR Version 3.1 Manual. Yale University, New Haven, CT.

Brünger,A. and Nilges,M. (1993) Computational challenges for macromolecular structure determinations by X-ray crystallography and solution NMR. Q. Rev. Biophys., 26, 49-125.

Campbell,P.G. and Andress,D.L. (1997) Insulin-like growth facor (IGF)binding protein-5-(201-218) region regulates hydroxyapatite and IGFI binding. Am. J. Physiol. Endocrinol. Metabol., 36, 1005-1013.

Chernausek,S.D., Smith,C.E., Duffin,K.L., Busby,W.H., Wright,G. and Clemmons,D.R. (1995) Proteolytic cleavage of insulin-like growth factor binding protein 4 (IGFBP-4). Localization of cleavage site to non-homologous region of native IGFBP-4. J. Biol. Chem., 270, 11377-11382.

Cieslar,C., Ross,A., Zink,T. and Holak,T.A. (1993) Efficiency in multidimensional NMR by optimized recording of time point-phase pairs in evolution periods and their selective linear transformation. J. Magn. Reson., 101, 97-101.

Clemmons,D.R. (1993) IGF binding proteins and their functions. Mol. Repr. Dev., 35, 368-375.

Clemmons,D.R. (1997) Insulin-like growth factor binding proteins and their role in controlling IGF actions. Cytokine Growth Factor Rev., 8, $45-62$.

Conover,C.A. (1995) Insulin-like growth factor binding protein proteolysis in bone cell models. Prog. Growth Factor Res., 6, 301-309.

Cooke,R.M., Harvey,T.S. and Campbell,I.D. (1991) Solution structure of human insulin-like growth factor 1: a nuclear magnetic resonance and restrained molecular dynamics study. Biochemistry, 30, 54845491.

Craik,D.J. and Wilce,J.A. (1997) Studies of protein-ligand interactions by NMR. Methods Mol. Biol., 60, 195-232.

Dhalluin,C., Wieruszeski,J.M. and Lippens,G. (1996) An improved hononuclear tocsy experiment with minimal water saturation. J. Magn. Reson., 111, 168-170.

Durham,S.K., Mohan,S., Liu,F., Baker,B.K., Lee,P.D., Hintz,R.L., Conover,C.A. and Powell, D.R. (1997) Bioactivity of a 29-kilodalton insulin-like growth factor binding protein-3 fragment present in excess in chronic renal failure serum. Pediatr. Res., 42, 335-341.

Edison,A.S., Abildgaard,F., Westler,W.M., Mooberry,E.S. and
Markley,J.L. (1994) Practical introduction to theory and implementation of multinuclear, multidimensional nuclear magnetic resonance experiments. Methods Enzymol., 239, 3-79.

Farrow,N.A. et al. (1994) Backbone dynamics of a free and a phosphopeptide-complexed Src homology 2 domain studied by ${ }^{15} \mathrm{~N}$ NMR relaxation. Biochemistry, 33, 5984-6003.

Folmer,R.H.A., Hilbers,C.W., Konings,R.N.H. and Hallenga,K. (1995) A ${ }^{13} \mathrm{C}$ - double-filtered NOESY with strongly reduced artifacts and improved sensitivity. J. Biomol. NMR, 5, 427-432.

Fowlkes,J.L., Serra,D.M., Rosenberg,C.K. and Thrailkill,K.M. (1995) Insulin-like growth factor (IGF)-binding protein-3 (IGFBP-3) functions as an IGF-reversible inhibitor of IGFBP-4 proteolysis. J. Biol. Chem., 270, 27481-27488.

Francis,G.L., Aplin,S.E., Milner,S.J., McNeil,K.A., Ballard,F.J. and Wallace,J.C. (1993) Insulin-like growth factor (IGF)-II binding to IGF-binding proteins and IGF receptors is modified by deletion of the $\mathrm{N}$-terminal hexapeptide or substitution of arginine for glutamate- 6 in IGF-II. Biochem. J., 293, 713-719.

Gill,R. et al. (1996) Engineering the C-region of human insuline-like growth factor-1. Implications for receptor binding. Protein Eng., 9, 1011-1019.

Gill,Z.P., Perks,C.M., Newcomb,P.V. and Holly,J.M. (1997) Insulin-like growth factor-binding protein (IGFBP-3) predisposes breast cancer cells to programmed cell death in a non-IGF-dependent manner. J. Biol. Chem., 272, 25602-25607.

Grzesiek,S. and Bax,A. (1992a) Correlating backbone amide and sidechain resonances in larger proteins by multiple relayed triple resonance NMR. J. Am. Chem. Soc., 114, 6291-6293.

Grzesiek,S. and Bax,A. (1992b) Improved 3D triple-resonance NMR techniques applied to a $31 \mathrm{kDa}$ protein. J. Magn. Reson., 96, 432-440.

Hashimoto,R., Ono,M., Fujiwara,H., Higashihashi,N., Yoshida,M., Enjohkimura,T. and Sakano,K. (1997) Binding sites and binding properties of binary and ternary complexes of Insulin-Like Growth Factor-II (IGF-II), IGF-binding protein-3 and acid-labile subunit. J. Biol. Chem., 272, 27936-27942.

Heding,A., Gill,R., Ogawa,Y., De Meyts,P. and Shymko,R.M. (1996) Biosensor measurement of the binding of insulin-like growth factors I and II and their analogues to the insulin-like growth factor-binding proteins. J. Biol. Chem., 271, 13948-13952.

Higo,H., Duan,C., Clemmons,D.R. and Herman,B. (1997) Retionic acid inhibits cell growth in HPV negative cervical carcinoma cells by induction of insulin-like growth factor binding protein-5 (IGFBP-5) secretion. Biochem. Biophys. Res. Commun., 239, 706-709.

Ho,M.N., Delgado,C.H., Owens,G.A. and Steller,M.A. (1997) Insulinlike growth factor-II participates in the biphasic effect of a gonadotropin-releasing hormone agonist on ovarian cancer cell growth. Fertil. Steril., 67, 870-876.

Hobba,G.D., Forbes,B.E., Parkinson,E.J., Francis,G.L. and Wallace,J.C. (1996) The insulin-like growth factor (IGF) binding site of bovine insulin-like growth factor binding protein-2 (bIGFBP-2) probed by iodination. J. Biol. Chem., 271, 30529-30536.

Hoffman,D.W. and Spicer,L.D. (1991) Isotopic labeling of specific amino acid types as an aid to NMR spectrum assignment of the methionine repressor protein. In Villafranca,J.J. (ed.) Techniques in Protein Chemistry II, Academic Press, San Diego, CA, pp. 409-419.

Holak,T.A., Gondol,D., Otlewski,J. and Wilusz,T. (1989) Determination of the complete three-dimensional structure of the trypsin inhibitor from squash seeds in aqueous solution by nuclear magnetic resonance and a combination of distance geometry and dynamical simulated annealing. J. Mol. Biol., 210, 635-648.

Hu,J.S. and Bax,A. (1996) Measurement of 3-bond ${ }^{13} \mathrm{C}-{ }^{13} \mathrm{C}$ J-couplings between carbonyl and carbonyl/carboxyl carbons in isotopically enriched proteins. J. Am. Chem. Soc., 118, 8170-8171.

Hu,J.S. and Bax,A. (1997a) $\chi^{1}$ angle information from a simple 2dimensional NMR experiment that identifies trans ${ }^{3} \mathrm{~J}(\mathrm{NC}) \gamma$ couplings in isotopically enriched proteins. J. Biomol. NMR, 9, 323-328.

Hu,J.S. and Bax,A. (1997b) Determination of $\phi$-angles and $\chi^{1}$-angles in proteins from ${ }^{13} \mathrm{C}^{13} \mathrm{C} 3$-bond J-couplings measured by 3 -dimensional heteronuclear NMR-how planar is the peptide-bond. J. Am. Chem. Soc., 119, 6360-6368.

Hu,J.S., Grzesiek,S. and Bax,A. (1997) 2-dimensional NMR methods for determining $\chi^{1}$ angles of aromatic residues in proteins from 3bond $\mathrm{J}\left(\mathrm{C}^{\prime} \mathrm{C}-\gamma\right)$ and $\mathrm{J}(\mathrm{NC}-\gamma)$ couplings. J. Am. Chem. Soc., 119, $1803-1804$.

Hull,E.W. (1994) Experimental aspects of two-dimensional NMR. In Croasmun,W.R and Carlson,R.M.K. (eds) Two-Dimensional NMRSpectroscopy, 2nd edn, VCH, Weihneim, pp. 67-437. 
Insight II User Guide (1995) Biosym/MSI, San Diego, CA.

Jahnke,W., Baur,M., Gemmecker,G. and Kessler,H. (1995) Improved accuracy of NMR structures by a modified NOESY-HSQC experiment. J. Magn. Reson., 106, 86-88.

Jansson,M., Uhlen,M. and Nilsson,B. (1997) Structural changes in insulin-like growth factor IGF I mutant proteins affecting binding kinetic rates to IGF binding protein 1 and IGF-I receptor. Biochemistry, 36, 4108-4117.

Jones,J.I., Gockerman,A., Busby,W.H., Jr., Camacho-Hubner,C. and Clemmons,D.R. (1993) Extracellular matrix contains insulin-like growth factor binding protein-5: potentiation of the effects of IGF-I. J. Cell Biol., 121, 679-687.

Kay,L.E., Xu,G.Y., Singer,A.U., Muhandiram, D.R. and Formankay,J.D. (1993) A gradient-enhanced HCCH-TOCSY experiment for recording side-chain ${ }^{1} \mathrm{H}$ and ${ }^{13} \mathrm{C}$ correlations in $\mathrm{H}_{2} \mathrm{O}$ samples of proteins. J. Magn. Reson., 101, 333-337.

Kiefer,M.C., Schmid,C., Waldvogel,M., Schlapfer,I., Futo,E., Masiarz,F.R., Green,K., Barr,P.J. and Zapf,J. (1992) Characterization of recombinant human insulin-like growth factor binding proteins 4, 5 and 6 produced in yeast. J. Biol. Chem., 267, 12692-12699.

Klaus,W., Broger,C., Gerber,P. and Senn,H. (1993) Determination of the disulphide bonding pattern in proteins by local and global analysis of nuclear magnetic resonance data. Application to flavoridin. J. Mol. Biol., 232, 897-906.

Koradi,R., Billeter,M. and Wüthrich,K. (1996) MOLMOL: a program for display and analysis of macromolecular structures. J. Mol. Graph., 14, 51-55.

Kupce,E. and Freeman,R. (1995) Stretched adiabatic pulses for broadband spin inversion. J. Magn. Reson., 117, 246-256.

Lippens,G., Dhalluin,C. and Wieruszeski,J.M. (1995) NOE spectroscopy, water suppression and water flip-back. Use of a water flip-back pulse in the homonuclear NOESY experiment. J. Biomol. NMR, 5, 327-331.

Loddick,S.A. et al. (1998) Displacement of insulin-like growth factors from their binding proteins as a potential treatment for stroke. Proc. Natl Acad. Sci. USA, 95, 1894-1898.

Löhr,F. and Rüterjans,H. (1997) $\mathrm{H}_{2} \mathrm{NCO}-\mathrm{E} . \mathrm{COSY}$, a simple method for the stereospecific assignment of side-chain amide protons in proteins. J. Magn. Reson., 124, 255-258.

Luthi,C., Roth,B.V. and Humbel,R.E. (1992) Mutants of human insulinlike growth factor II (IGF II). Expression and characterization of truncated IGF II and of two naturally occurring variants. Eur. J. Biochem., 205, 483-490.

Marion,D., Ikura,M., Tschudin,R. and Bax,A. (1989) Rapid recording of 2D NMR-spectra without phase cycling-application to the study of hydrogen-exchange in proteins. J. Magn. Reson., 85, 393-399.

Mohan,S., Nakao,Y., Honda,Y., Landale,E., Leser,U., Dony,C., Lang,K. and Baylink, D.J. (1995) Studies on the mechanisms by which insulinlike growth factor (IGF) binding protein-4 (IGFBP-4) and IGFBP-5 modulate IGF actions in bone cells. J. Biol. Chem., 270, 20424-20431.

Mori,S., Abeygunawardana,C., Johnson,M.O. and Vanzij1,P.C.M. (1995) Improved sensitivity of HSQC spectra of exchanging protons at short interscan delays using a new fast HSQC (FHSQC) detection scheme that avoids water saturation. J. Magn. Reson., 108, 94-98.

Muchmore,D.C., McIntosh,L.P., Russell,C.B., Anderson,D.E. and Dahlquist,F.W. (1989) Expression and nitrogen-15 labeling of proteins for proton and nitrogen-15 nuclear magnetic resonance. Methods Enzymol., 177, 44-73.

Otting,G. and Wüthrich,K. (1990) Heteronuclear filters in twodimensional ${ }^{1} \mathrm{H},{ }^{1} \mathrm{H}-\mathrm{NMR}$ spectroscopy: combined use with isotope labelling for studies of macromolecular conformation and intramolecular interactions. Q. Rev. Biophys., 23, 39-96.

Qin,X., Strong,D.D., Baylink,D.J. and Mohan,S.J (1998) Structurefunction analysis of the human insulin-like growth factor binding protein-4. J. Biol. Chem., 273, 23509-23516.

Rajaram,S., Baylink,D.J. and Mohan,S. (1997) Insulin-like growth factorbinding proteins in serum and other biological fluids. Endocrinol. Rev., 18, 801-831.

Rance,M., Sorensen,O.W., Bodenhausen,G., Wagner,G., Ernst,R.R. and Wüthrich,K. (1983) Improved spectral resolution in COSY ${ }^{1} \mathrm{H}-\mathrm{NMR}$ spectra of proteins via double quantum filtering. Biochem. Biophys. Res. Commun., 117, 479-485.

Rosen,C.J. et al. (1997) Circulating and skeletal insulin-like growth factor-I (IGF-I) concentrations in two inbred strains of mice with different bone mineral densities. Bone, 21, 217-223.

Shaka,A.J., Lee,C.J. and Pines,A. (1988) Iterative schemes for bilinear operators-application to spin decoupling. J. Magn. Reson., 77, 274-293.
Silver,M.S., Joseph,R.I. and Hoult,D.I. (1984) Highly selective $\pi / 2$ and $\pi$ pulse generation. J. Magn. Reson. 59, 347-351.

Sklenar,V., Piotto,M., Leppik,R. and Saudek,V. (1993) Gradient-tailored water suppression for ${ }^{1} \mathrm{H}_{-}{ }^{15} \mathrm{~N}$ HSQC experiments optimized to retain full sensitivity. J. Magn. Reson. 102, 241-245.

Sommer,A., Spratt,S.K., Tatsuno,G.P., Tressel,T., Lee,R. and Maack,C.A. (1993) Properties of glycosylated and non-glycosylated human recombinant IGF binding protein-3 (IGFBP-3). Growth Regul., 3, 46-49.

Spencer,E.M. and Chan,K. (1995) A 3-dimensional model for the insulinlike growth factor binding proteins (IGFBPs); supporting evidence using the structural determinants of the IGF binding site on IGFBP3. Prog. Growth Factor Res. 6, 209-214.

Stewart,C.E. and Rotwein,P. (1996) Growth, differentiation and survival: multiple physiological functions for insulin-like growth factors. Physiol. Rev., 76, 1005-1026.

Stonehouse,J., Clowes,R.T., Shaw,G.L., Keeler,J. and Laue,E.D. (1995) Minimization of sensitivity losses due to the use of gradient pulses in triple-resonance NMR of proteins. J. Biomol. NMR, 5, 226-232.

Talluri,S. and Wagner,G. (1996) An optimized 3D NOESY-HSQC. J. Magn. Reson., 112, 200-205.

Terasawa,H., Kohda,D., Hatanaka,H., Nagata,K., Higashihashi,N., Fujiwara,H., Sakano,K. and Inagaki,F. (1994) Solution structure of human insulin-like growth factor II; recognition sites for receptors and binding proteins. EMBO J., 13, 5590-5597.

Torres,A.M., Forbes,B.E., Aplin,S.E., Wallace,J.C., Francis,G.L. and Norton,R.S. (1995) Solution structure of human insulin-like growth factor II. Relationship to receptor and binding protein interactions. J. Mol. Biol., 248, 385-401.

Vuister,G.W. and Bax,A. (1993) Quantitative J correlation-a new approach for measuring homonuclear 3-bond $\mathrm{J}(\mathrm{H}(\mathrm{N}) \mathrm{H}(\alpha))$ couplingconstants in ${ }^{15} \mathrm{~N}$-enriched proteins. J. Am. Chem. Soc., 115, 7772-7777.

Walsh,G. (1995) Nervous excitement over neuotrophic factors. Biotechnology 13, 1167-1171.

Wang,J.F., Hampton,B., Mehlman,T., Burgess,W.H. and Rechler,M.M. (1988) Isolation of a biologically active fragment from the carboxy terminus of the fetal rat binding protein for insulin-like growth factors. Biochem. Biophys. Res. Commun., 157, 718-726.

Werner,H. and LeRoth,D. (1998) The role of the insulin-like growth factor system in human cancer. Adv. Cancer Res., 68, 183-223.

Wüthrich,K. (1986) NMR of Proteins and Nucleic Acids. John Wiley, New York, NY.

Yeh,L.C., Adamo,M.L., Olson,M.S. and Lee,J.C. (1997) Osteogenic protein-1 and insulin-like growth factor I synergistically stimulate rat osteoblastic cell differentiation and proliferation. Endocrinology, 138, 4181-4190.

Zapf,J., Kiefer,M., Merryweather,J., Musiarz,F., Bauer,D., Born,W., Fischer,J.A. and Froesch,E.R. (1990) Isolation from adult human serum of four insulin-like growth factor (IGF) binding proteins and molecular cloning of one of them that is increased by IGF I administration and in extrapancreatic tumor hypoglycemia J. Biol. Chem., 265, 14892-14898.

Zhang,O. and Forman-Kay,J.D. (1995) Structural characterization of folded and unfolded states of an $\mathrm{SH} 3$ domain in equilibrium in aqueous buffer. Biochemistry, 34, 6784-6794.

Zwahlen,C., Legault,P., Vincent,S.J.F., Greenblatt,J., Konrat,R. and Kay,L.E. (1997) Methods for measurement of intermolecular NOEs by multinuclear NMR spectroscopy-application to a bacteriophage lambda N-peptide/box RNA complex. J. Am. Chem. Soc., 119, 6711-6721.

Received May 27, 1998; revised September 16, 1998; accepted September 17, 1998 